\title{
Productivity, Restructuring, and the Gains from Takeovers*
}

\author{
Xiaoyang $\mathrm{Li}^{\dagger}$ \\ Ross School of Business, University of Michigan \\ JOB MARKET PAPER
}

January 3, 2011

\begin{abstract}
Little is known about the underlying sources of gains from takeovers. Using plant-level data from the U.S. Census Bureau, I show that one source of gains is increased productivity of capital and labor in target plants. In particular, acquirers significantly reduce investments, wages, and employment in target plants, though output is unchanged relative to comparable plants. Acquirers also aggressively shut down target plants, especially those that are inefficient. Moreover, these changes help explain the merging firms' announcement returns. The total announcement returns to the combined firm are driven by improvements in target firm's productivity, rather than cutbacks in wages and employment. Also, targets with greater post-takeover productivity improvements receive higher offer premiums from acquirers. These results provide some of the first empirical evidence on the direct relation between productivity, labor, and stock returns in the context of takeovers.
\end{abstract}

Keywords: Takeovers, merger announcement returns, productivity, wages and employment

JEL Classification: G34, D24, J30

${ }^{*}$ I am indebted to members of my dissertation committee, Amy Dittmar (co-chair), Jan Svejnar (co-chair), Charlie Brown, Francine Lafontaine, Amiyatosh Purnanandam, and Uday Rajan for their guidance and support. Suggestions provided by Kenneth Ahern and Angie Low greatly improved this paper. I also thank Jonathan Berk, Sugato Bhattarcharyya, Ing-haw Cheng, Han Kim, Jagadeesh Sivadasan, Liu Yang, Xianming Zhou, and seminar participants at the University of Michigan Finance and Business Economics Brownbag workshops, the 2010 International Industrial Organization Conference, the 2010 European Financial Association Annual Meeting, the 2010 Financial Management Association Annual Meeting, and the 7th Annual Conference on Corporate Finance at Washington University for helpful comments. The research was conducted when the author was a Special Sworn Status researcher of the U.S. Census Bureau at the Michigan Research Data Center. Any opinions and conclusions expressed herein are those of the author and do not necessarily represent the views of the U.S. Census Bureau. All results have been reviewed to ensure that no confidential information is disclosed. I acknowledge the generous financial support from Ewing Marion Kauffman Foundation. All errors are my own.

${ }^{\dagger}$ Stephen M. Ross School of Business, University of Michigan, 701 Tappan Street, Ann Arbor, MI 48109-1234. Telephone: (734) 936-0391. Email: lixy@umich.edu 


\section{Introduction}

Though it is well documented that takeovers increase the combined equity value of targets and acquirers, relatively little is known about the sources of such gains (Andrade, Mitchell, and Stafford, 2001). In an attempt to shed light on the sources of gains, several studies examine changes in plant-level productivity using data from the U.S. Census Bureau. For instance, Maksimovic and Phillips (2001) show that takeovers are followed by improved productivity ${ }_{1}^{1}$ These studies, however, do not attempt to identify the detailed mechanisms that affect changes in productivity. Yet identifying these mechanisms is critical for both researchers and practitioners to gain insights into what factors influence a merger's success or failure. In addition, surprisingly little empirical evidence exists on the direct relation between announcement period stock returns and real economic gains or losses. The goal of this study, therefore, is to uncover the underlying sources of gains from takeovers and to relate them to the cross-sectional differences in announcement returns.

In this paper, I show that acquiring firms increase the productivity of targets through more efficient use of investments and labor and through aggressive plant closures. I also find that the combined firms' announcement returns reflect these underlying efficiency improvements. I conduct the analysis on 1,430 mergers completed between 1981 and 2002, using data from the Securities Data Company's Mergers and Acquisitions database and confidential plant-level data from the U.S. Census Bureau. These data allow me to identify detailed changes in plant-level output and input from before to after the takeover. I first examine whether takeovers affect targets' total factor productivity (TFP). Using a differencesin-differences regression approach, I find that the target plant's TFP experiences net improvement relative to comparable plants following a takeover.

I next pinpoint the detailed channels through which these productivity gains are created. I address this question by separating TFP into output and input components and comparing changes to output vis-á-vis input following a takeover. I show that capital expenditures, wages, and employment all experience substantial declines while the output remains constant, relative to comparable plants. Essentially, the acquiring firm produces the same amount of output using less input. This indicates that increases in productivity stem primarily from acquiring firms' more efficient use of investments and labor. I also find that employee layoffs are concentrated mostly among non-production workers in target plants, which supports the hypothesis that acquirers reduce management slack and transfer its own management know-how. These findings are consistent with anecdotal evidences. For example, after the pharmaceutical firms Merck and Schering-Plough merged in late 2009, the new firm announced

\footnotetext{
${ }^{1}$ Other studies, including Lichtenberg (1992), McGuckin and Nguyen (1995), Yang (2008), and Maksimovic, Phillips, and Prabhala (2008) also find similar results.
} 
a restructuring initiative to streamline its operations to achieve synergy. In an open announcement, Richard Clark, CEO of Merck, announced that 16,000 jobs would be cut (15 percent of the workforce) and that this restructuring program was intended to save $\$ 2.6$ billion to $\$ 3$ billion by 2012 , accounting for nearly 80 percent of the total synergy benefits the two firms had set to gain $2^{2}$

In addition to downsizing and making more productive use of inputs in the continuing plants, the acquirers also aggressively shut down target plants. According to my findings, three years following a takeover, target plants are 6.9 percentage points more likely to be shut down than control plants. In addition, plants with lower initial TFP are more likely to be closed.

Building on these findings, I take the current research a step further by connecting a target firm's productivity gains and labor cost savings to combined firm's announcement returns. The market for corporate control literature proposes that the total gains to shareholders reflect value creation via efficient allocation of resources (Jensen and Ruback, 1983). I refer to this proposition as the efficiency creation hypothesis. Some dispute this claim by arguing that gains to shareholders simply represent wealth redistribution from other stakeholders such as government, bondholders, consumers, and most notably from employees (Shleifer and Summers, 1988). I refer to this argument as the employee wealth redistribution hypothesis. Under the efficiency creation hypothesis, gains to the combined firm's shareholders capitalize future productivity improvements. In contrast, under the employee wealth redistribution hypothesis, such gains come largely from employee wealth losses, potentially through wages and employment reductions .

To test the efficiency creation hypothesis versus employee wealth redistribution hypothesis, I construct two variables $\triangle \mathrm{TFP}$ and $\triangle$ Payroll measuring target firms' pre- and post-takeover percentage changes in productivity and in payroll (total salaries and wages) and regress the combined announcement returns on these two variables. The analysis on the combined firm's announcement return is concerned with the total synergy gains a merger generates. The results show that post-takeover improvements in productivity $(\triangle \mathrm{TFP})$ are positively associated with the total synergy gains, especially when the target is relatively large compared with the acquirer. Ceteris paribus, compared with acquiring a target at the 25 th percentile of $\triangle \mathrm{TFP}$, acquiring a target at the 75 th percentile increases the combined three-day announcement returns by 1 percentage points. If the target's pre-takeover market value is half of the acquirer's, such a change increases the combined returns by about 2.5 percentage points. The economic significance of the point estimates is considerable given that the sample median of the combined return is about 3.5 percent. In contrast, I find no statistically significant relation between combined announcement returns and labor cost savings ( $\Delta$ Payroll), which contradicts the

\footnotetext{
${ }^{2}$ http://blogs.wsj.com/health/2010/01/06/what-mercks-ceo-said-today-about-possible-job-cuts/mod=yahoohs
} 
employee wealth redistribution hypothesis.

I next investigate the gains to the target firm and the acquiring firm separately. Prior literature consistently documents that targets receive high offer premiums from acquirers and capture virtually all of the joint gains (e.g., Moeller, Schlingemann, and Stulz, 2004). Unfortunately, extant studies have yet to find specific economic gains that warrant such high premiums (Betton, Eckbo, and Thorburn, 2008). Many attribute the high premiums to behavioral distortions (Roll, 1986; Malmendier and Tate, 2008) and agency conflicts (Wulf, 2004; Hartzell, Ofek, and Yermack, 2004; Moeller, 2005). In this study, I hypothesize that the offer premiums are related to the ultimate benefits to acquirers, with target performance improvements under new management being an important part of these benefits. I examine the relation between targets' productivity improvements and the offer premiums they receive and find that target firms with greater post-takeover productivity improvements receive higher premiums from acquirers. Other things being equal, an acquirer pays a target with $\Delta \mathrm{TFP}$ at the 75th percentile about 10 percentage points higher offer premium than a target at the 25th percentile. This statistically and economically significant effect is robust to the inclusion of a "reference point" variable recently proposed by Baker, Pan, and Wurgler (2010). This result is consistent with insights from Rhodes-Kropf and Robinson (2008), who emphasize the target's future expected surplus in determining bargaining outcomes. Lastly, I look at the acquirers' own announcement returns. However, I do not find a statistically significant relation between improvements in productivity and acquirers' announcement returns. Overall, the evidence suggests that gains in productivity indeed create value for the shareholders of the combined firm with the target firms' shareholders capturing the majority of the joint gains.

This paper makes several contributions to the literature on corporate takeovers. First, I present some of the direct empirical results on the channels that affect productivity improvements following takeovers. Existing evidence on channels comes mostly from a few clinical studies (see, e.g., Kaplan, 2000; Kaplan, Mitchell, and Wruck, 2000; Hietala, Kaplan, and Robinson, 2003). Contrary to prior research, which often attributes takeover efficiency gains to a broad notion of "synergy" or "better management", I provide substantiating evidence by peering inside the black box of target plants.

Second, this study adds to the literature that explains the cross-sectional variation of merging firms' announcement returns. Most existing studies attempt to regress announcement returns on various imperfect proxies for economic gains such as Tobin's Q (Lang, Stulz, and Walkling, 1989; Servaes, 1991), insider and analyst forecasts of synergies (Houston, James, and Ryngaert, 2001; Devos, Kadapakkam, and Krishnamurthy, 2009), operating cash flow (Healy, Palepu, and Ruback, 1992), corporate governance measures (Masulis, Wang, and Xie, 2007; Wang and Xie, 2009), and product 
market differentiation (Hoberg and Phillips, 2010). My findings corroborate the conclusion that wealth gains to shareholders reflect expectations of improved corporate performance. The crucial difference is that I regress announcement returns directly on plant-level productivity measure, which is a more fundamental determinant of economic efficiency and is less subject to noise in accounting information surrounding the mergers. To the best of my knowledge, this is the first study that explores the relation between stock returns and plant-level productivity in the context of takeovers $3^{3}$

This paper also complements the aforementioned studies by jointly testing the redistribution theory of takeovers from the employees' perspective. While efficiency improvement is socially desirable, shareholder gains from rent expropriation from employees may not be. The potential for such wealth transfers in mergers has become increasingly contentious, especially among policymakers and the popular press. Existing research mostly finds a small scale of wealth redistribution from labor (e.g., Rosett, 1990; Pontiff, Shleifer, and Weisbach, 1990). Due to data limitations and focus, few studies test the efficiency creation hypothesis versus employee wealth distribution hypothesis head-to-head. This is problematic because the two are often intertwined. For example, an increase in profits could be a result of either efficiency gains or wealth transfer from employees; wage or job losses from employees may well help create efficiency gains. This paper makes the first unified attempt to test these two hypotheses. In sum, I show that improvements in productivity, rather than wealth losses from labor, are associated with higher announcement returns for the combined firm. My findings suggest that takeovers indeed involve wealth transfers from target firm's employees to shareholders, but the extent of such transfers is relatively small. Despite the conspicuous role employees play in mergers and acquisitions, relatively little attention has been paid to labor in the corporate control literature. This study, therefore, contributes to a growing body of literature on the role of labor in corporate takeovers and restructuring (e.g., Pagano and Volpin, 2005; Rauh, 2006; Atanassov and Kim, 2009).

The rest of the paper is structured as follows. In the following section, I present the research objectives and develop testable hypotheses drawing from existing literature. Section 3 describes the data, sample, and variables. Section 4 analyzes the effect of takeovers on productive efficiency and other related aspects of operation. In Section 5, I investigate possible determinants of merger announcement returns from the perspective of productivity and labor costs changes. Section 6 concludes.

\footnotetext{
${ }^{3}$ This approach originates from Schoar (2002), who shows that stock prices track total factor productivity in both conglomerate and single-segment firms.
} 


\section{Hypothesis Development and Related Literature}

In this study, I attempt to address two questions:

(1) How do takeovers create productivity gains?

(2) Do announcement returns for the combined firm reflect these productivity gains?

In this section, I discuss the prior literature related to these questions and present hypotheses to guide the empirical analysis.

\subsection{Effect of Takeovers on Productive Efficiency}

Traditional corporate finance theories portray takeovers as a market for corporate control, which in turn fosters an efficient allocation of resources. The market discipline hypothesis (also referred to as the inefficient management hypothesis) proposes that managers who pursue objectives other than maximizing profit often fall prey to more efficient firms, which improve efficiency by displacing the managers in the target firm (Martin and McConnell, 1991). A related view holds that takeovers aim to create synergies, which can arise from exploiting increased market power, economies of scale, eliminating duplicate efforts, and combining complementary resources (Hoberg and Phillips, 2010). If the acquisition is driven by either market discipline or synergy creation, then after a takeover, I expect the following hypothesis to hold:

\section{H1: The productivity of the target firm increases after the takeover.}

Agency theories, however, often view mergers and acquisitions as investment actions driven primarily by the CEO's personal objectives — either to build an empire (Jensen, 1986) or to entrench their power over the firm (Shleifer and Vishny, 1989). If an acquisition is influenced by conflicts of interest between managers and owners of the firm, the opposite of $\mathbf{H 1}$ will follow:

H1a: The productivity of the target firm does not necessarily increase after the takeover.

Except for a few studies (see, e.g., Ravenscraft and Scherer, 1989; Ghosh, 2001), most studies conclude that takeovers improve target firm's plant-level productivity (see, e.g., Lichtenberg, 1992; McGuckin and Nguyen, 1995; Maksimovic and Phillips, 2001; Maksimovic, Phillips, and Prabhala, 2008; Yang, 2008). None of these studies, however, explores how takeovers actually achieve productivity improvements, which is the focus of the current study. 


\subsection{Sources of Efficiency Gains}

Acquirers have strong incentives to restructure the target firm in order to improve efficiency. Labor expenses and investments account for a large portion of a firm's outlay of financial resource. Meanwhile, corporate decisions on these two expenditures are prone to manager-shareholder agency problems that destroy efficiency. Bertrand and Mullainathan (2003) show that CEOs prefer a "quiet life" by appeasing workers (especially white-collar workers) with excess wages. Jensen's (1986) free cash flow theory hypothesizes that CEOs sacrifice firm's profitability for size by investing in negative net present value projects. Therefore, adjusting wages, employment, and investment can not only reduce costs, but also increase productive efficiencies. The extreme of such adjustment is to close the entire plant. I thus propose the following hypothesis to test the underlying mechanisms through which productivity might improve:

H2: The acquirer achieves productivity improvements in the target firm through reductions in wages and employment, cutbacks in investment, and/or plant closures.

Lichtenberg and Siegel (1990a,b) document that ownership changes are followed by substantial reductions in administrative overhead, especially the number of "central-office" employees. Such actions are known to create values in leverage buyouts in the 1980s (Shleifer and Vishny, 1988). Similarly, Kaplan (1989) documents that capital expenditures declined substantially in a sample of firms involved in management buyouts in the 1980s. Yet Servaes (1994) finds little evidence of investment cutbacks in a sample of 700 firms that went private from 1972 to 1987.

Most of these studies obtain their conclusions using samples of takeovers that occurred in the early 1980s, which were characterized by a flurry of hostile takeovers and leveraged and management

buyouts. The landscape of takeovers has changed dramatically since then; thus, updating the evidence is warranted.

Maksimovic and Phillips $(2001,2002)$ argue that a firm engages in asset purchases to exploit its comparative advantage in operating certain segments. Maksimovic, Phillips, and Prabhala (2008) show that acquirers redraw firm's boundary by retaining assets in which they have a comparative advantage in operations, but selling assets peripheral to their operations. My approach differs from their by examining whether acquirers shut down underperforming plants expediently.

H2 essentially implies that acquiring firms potentially create efficiency gains by reducing existing inefficiencies such as redundant employment, non-profit-maximizing wages, excess investment, and under-performing plants in target firms. The necessary condition for these actions to be efficiencyenhancing is that the amount of output does not drop correspondingly. An alternative to H2, as shown 
in McGuckin and Nguyen (2001), is the following:

H2a: The acquirer achieves productivity improvements in the target firm through increases in wages, employment, and investment, which lead to expansions in output.

\subsection{Determinants of Combined Announcement Returns}

H1 and H2 are related to whether and, especially how takeovers affect targets productivity. To the extent that these activities are anticipated by the stock market, stock price reactions to merger announcement should capitalize these economic gains and/losses.

Prior literature consistently documents that mergers increase shareholder value for the target and acquiring firm combined. Disagreement remains, however, regarding the sources of these shareholder wealth gains. Two competing theories have been put forward to explain the total gains: Efficiency creation (Jensen, 1986) and wealth redistribution (Shleifer and Summers, 1988). The efficiency creation theory reasons that in an efficient capital market, the combined gains to shareholders following the merger announcement reflect improved expectations of the merging firms' operating performance. Therefore, the following hypothesis is proposed:

H3 (Efficiency creation hypothesis): The total gains to the combined firm's shareholders capitalize future gains in productivity in the target firm.

Alternatively, the wealth redistribution theory contends that wealth gains to shareholders simply represent wealth losses from other stakeholders. Employees in the target firms are particularly disadvantaged subsequent to a takeover. Presumably, new managers face lesser resistance from the target firm's employees because there is greater understanding that firms must consolidate operations after a merger. Shleifer and Summers (1988) argue that takeovers are in part motivated by the opportunity to renege on implicit labor contracts and that transfers from employees to shareholders account for a large part of the takeover premium. Following this logic, I proposes the following hypothesis to examine wealth redistribution as a source of gains to shareholders:

H4 (Employee wealth redistribution hypothesis): The total gains to the combined firm's shareholders come partly from employee wealth losses in the target firm, potentially through reduced wages and/or employee layoffs.

A large literature tests the efficiency creation hypothesis by regressing announcement returns on some measures of economic gains. Using Tobin's Q as proxy for managerial performance, Lang, Stulz, 
and Walkling (1989) and Servaes (1991) document that total takeover gain is highest when a wellmanaged (high Q) firm acquires a poorly-managed (low Q) target. Masulis, Wang, and Xie (2007) and Wang and Xie (2009) find similar evidence using corporate governance measures (G-index). From a sample of the 50 largest mergers between 1979 and 1984, Healy, Palepu, and Ruback (1992) find a positive correlation between post-merger increases in operating cash flows and announcements returns. Based on a text-based measure for production market competition and differentiation, Hoberg and Phillips (2010) show that mergers create more value when the potential product market synergy (creating new products that increase product differentiation) is greater. Houston, James, and Ryngaert (2001) show that merger gains are associated with the acquiring firm's management forecasts of synergies in a sample of 41 banking mergers. Drawing information from the Value Line, Devos, Kadapakkam, and Krishnamurthy (2009) find that announcement returns correspond to analyst forecasts of synergies. While these studies all conclude that gains to shareholders reflect efficiency improvements, their approaches are subject to the criticisms that these variables (Q, governance, cash flow, product market competition, and synergy forecasts) represent at best noisy measures of economic gains.

On the other hand, large-sample empirical support for the employee wealth redistribution hypothesis has been inconclusive and rather limited. Brown and Medoff (1988) report evidence that mergers are associated with wage declines of about 4 percent and employment growth of about 2 percent in a sample of small firms in Michigan. McGuckin and Nguyen (2001) find that ownership changes are associated with positive outcomes in terms of jobs, wages, and plant survival probability. Ouimet and Zarutskie (2010) also show that average employee wage increases following a merger. In a sample of 413 takeovers between 1981 and 1988, Pontiff, Shleifer, and Weisbach (1990) report that pension funds reversions are more likely following a hostile takeover, but these pension reversions amount to a small portion of the takeover premiums. Rosett (1990) concludes that a wealth transfer from workers to shareholders accounts for 10 percent of the hostile-takeover premium, and only 5 percent for friendly takeovers. The majority of evidence seems to suggest that wealth redistribution from labor alone cannot explain gains to the target and acquiring firm shareholders.

An empirical challenge arises because efficiency creation hypothesis and employee wealth redistribution hypothesis are not mutually exclusive. While wage reductions and employee layoffs redistribute wealth to shareholders, they are also likely to be part of a restructuring process that increases productive efficiency. As a result, simply looking at the relation between announcement returns and changes in wages and employment is insufficient to distinguish one from the other. I address this challenge through two additional empirical exercises. First, in addition to focusing on wage and employment changes, I also examine changes to fringe benefits (pension benefits, unemployment benefits, and health 
insurance etc.) as a source of employee wealth redistribution. Second, I estimate the redistribution ratio (defined as the dollar changes in shareholder wealth in response to a dollar cut in employee wealth) between employee wealth and shareholder wealth to test whether this ratio is greater than one. If this redistribution ratio is greater than one, employee wealth cuts probably entail additional gains to shareholders beyond the pure transfer. I discuss the details of these two tests in Section 5.4.

\subsection{Determinants of Offer Premiums}

I next turn attention to the offer premiums that targets receive from acquirers. A robust empirical finding in the literature is that the target firms' shareholders capture most of the joint gains 4 For example, Moeller, Schlingemann, and Stulz (2004) report that targets receive premiums of about 65 percent and acquirers' three-day announcement returns are only about 1 percent. Little is known about what economic factors, if any, drive such high offer premiums 5 One influential view by Roll (1986) postulates that such a high offer premium results from the acquirer CEO's hubris. Even if the acquiring firm can benefit from acquiring the target, the acquiring firm overpays for these benefits due to excessive self-confidence. Recently, Baker, Pan, and Wurgler (2010) find that offer premiums are geared toward the target's past 52-week high price pre-merger. They interpret the evidence as support for the "reference point" hypothesis of merger premiums. The target firm's agency conflicts can also affect the target premiums. Wulf (2004) and Hartzell, Ofek, and Yermack (2004) both suggest that target's CEO trades private benefits for premiums. In a similar vein, Moeller (2005) shows that target shareholder control, proxied by low target CEO share ownership, low fractions of inside directors, and the presence of large outside blockholders is positively correlated with offer premiums.

These behavioral and agency based explanations for offer premiums are in contrast to the efficiencydriven explanation. Rhodes-Kropf and Robinson (2008) argue that the complementary nature of target's asset to acquirer's asset and target's future expected surplus determine its bargaining position. If targets' productivity improvements constitute an important source of benefits to acquirers, targets with greater ex post productivity improvements are in a relative stronger bargaining position due to their better future prospects. Therefore, they are able to demand higher premiums. I thus propose the following hypothesis to examine whether offer premiums can be explained by target's post-takeover productivity gains.

\section{H5: Targets with greater ex post productivity improvements receive higher offer pre-}

\footnotetext{
${ }^{4}$ Ahern (2010) provides contrary results based on inference from division of merger gains in dollar value.

${ }^{5}$ Bargeron, Schlingemann, Stulz, and Zutter (2008) find that privates acquirers pay lower premiums than publiclylisted acquirers. Officer (2003) and Bates and Lemmon (2003) show that offer premiums are greater when the SDC indicates the existence of a target termination agreement.
} 
miums from acquirers.

\section{Data Sample and Variable Construction}

I exploit plant-level data from the U.S. Census Bureau to test the above hypotheses. The main data used in this paper come from a linked sample between the Annual Survey of Manufacturers (ASM), the Census of Manufacturers (CMF), Longitudinal Business Database (LBD), maintained at the U.S. Census Bureau, and the Securities Data Company's (SDC) Mergers and Acquisitions database. This section describes the sample.

\subsection{Identifying Mergers and Acquisitions}

The data on mergers and acquisitions are taken from the SDC's U.S. Mergers and Acquisitions database. Only deals completed between January 1, 1981 and December 31, 2002 and completed within 360 days of the announcement are included 6 The transaction value of the deal is restricted to be at least 1 million U.S. dollars and the targets must be publicly-listed with stock prices available from the Center for Research in Security Prices (CRSP). Acquirers must own less than 50 percent of the target's shares before and more than 50 percent after the merger. Acquirers may be public, private, or subsidiaries of public or private firms. I then match these targets (using the target's CUSIP and ticker) to firms in the ASM and CMF database 7 A total of 1,430 matched target firms constitute the main sample used in this study.

Table 1 displays the composition of the sample across time and describes the basic characteristics of these matched deals. The time period 1981-2002 covers two merger waves. The number of transactions begins to increase in the 1980s, peaks in the late 1980s, and declines in the early 1990s, before picking up again toward the end of the sample period. The deal value for the sample is quite large due to sample restrictions (publicly-listed target operating plants in the manufacturing sector), averaging about 950 million dollars. The average three-day announcement period abnormal return for target firms is fairly stable, at about 25 percent throughout the sample period. A little more than half of these target firms (770) are acquired by another publicly-listed firm with information available from the CRSP. On average, the sample mean of the three-day announcement abnormal return for the acquiring firm is around zero. These figures buttress the well-established finding that mergers clearly benefit target

\footnotetext{
${ }^{6}$ I restrict the deals to be completed by 2002 because current Economic Census data is available until 2005 and I want to follow the plants three years after the merger. I require the deals to be completed within 360 days so that I can identify the merger completion year cleanly.

${ }^{7}$ Previous studies including Maksimovic and Phillips (2001) and Schoar (2002) both use Longitudinal Research Database (LRD). Census no longer maintains LRD, but LRD is drawn from ASM and CMF.
} 
shareholders while, on average, the acquiring firm's shareholder do not lose. The median value of the weighted sum of the announcement returns for the target and the acquirer combined in my sample is about 3.5 percent. This seems to suggest that these mergers indeed create value to the shareholders.

\subsection{Matching Mergers to Census Establishment Data}

Plant-level information comes from ASM and CMF. These databases include information on total value of shipments, expenditures on intermediate and primary inputs, and other input measures such as materials, energy, and electricity costs. They also provide detailed information on wage and employment which are covered only sparsely in COMPUSTAT. The ASM and CMF database also circumvent the problem with accounting data which are affected by managerial decisions especially after a merger (Houston, James, and Ryngaert, 2001). The economic census takes place in years ending with "2" and "7", and covers approximately 350,000 manufacturing plants each time. The ASM typically samples about 50,000 plants in non-census years. Plants with more than 250 employees 8 and plants that are part of very large firms are included by sample design. Some 40,000 other plants are selected with probability proportional to a composite measure of their size. Once a plant is surveyed, the ASM continues surveying this plant to form a five-year panel.

Once I identify a target firm, I use the firm-plant link to identify all the plants this target firm owns one year prior to a merger. Plants surveyed by the Census Bureau have a permanent establishment identifier (LBDNUM), which remains invariant to ownership changes. This allows me to follow the exact same plants before and after the takeovers. I choose a three-year window, centered around the year when the merger is completed, to track the dynamics of the target plants.9 I provide more details about how the sample is constructed in Appendix B.

\subsection{Framework and Variables}

In this section, I sketch a simple Cobb-Douglas production function to describe the framework and variables used in later estimations. Assume that a plant uses three factors, capital, labor, and material to produce output $Y$,

$$
Y=A K^{\alpha} L^{\beta} M^{\gamma}
$$

where $Y$ denotes the dollar value of the output; $A$ denotes a constant term measuring the efficiency with which the plant uses its inputs in production (total factor productivity); $L$ denotes labor; $K$ denotes capital; and $M$ denotes material cost.

\footnotetext{
${ }^{8}$ Starting from 2003, the Census has raised the threshold to 1,000 employees.

${ }^{9}$ Schoar (2002) and Maksimovic, Phillips, and Prabhala (2008) also choose a three-year window in their analyses.
} 
Let $W$ denote total payroll, which equals the product of the number of employees and their average annual wage, and $I$ denote capital expenditure, which equals changes in capital stock. The plant's before-tax cash flow from operations can be expressed roughly as:

$$
\Pi=Y-W-I-M
$$

This cash flow variable differs from a typical cash flow measure because the data do not measure firm-level costs, such as interest expenses, advertising, and research and development. Changes in operating cash flow, then, can be expressed as a function of pre- and post-takeover changes in productivity $\Delta A ;$ total payroll $\Delta W$; capital expenditures $\Delta I ;$ and material costs $\Delta M$.

$$
\Delta \Pi=f(\Delta A, \Delta W, \Delta I, \Delta M)
$$

Assuming that merger announcement abnormal returns capitalize the future cash flow gains or losses as in Equation (3) by a proper discount factor $r$, I can therefore link changes in production primitives to changes in the market value of the firm. Specifically, I use Equation (4) to test whether changes in productivity and payroll explain changes in announcement returns, denoted as $\Delta V$.

$$
\begin{aligned}
& \text { Assuming that } \Delta V \sim \frac{\Delta \Pi}{r} \text { then, } \\
& \Delta V=f(\Delta A, \Delta W, \Delta I, \Delta M)+\epsilon
\end{aligned}
$$

Total factor productivity (TFP) is used to measure the plant's overall efficiency. I follow Lichtenberg (1992) and Bertrand and Mullainathan (2003) by estimating the following ordinary least squares (OLS) regression separately for each three-digit standard industrial classification (SIC) industry and for each year. The estimation residual term $\epsilon$ is therefore the TFP measure.

$$
\log \left(\text { Output }_{i}\right)=\alpha+\beta_{1} \log \left(\text { Payroll }_{i}\right)+\beta_{2} \log \left(\text { Capital }_{i}\right)+\beta_{3} \log \left(\text { Material }_{i}\right)+\epsilon_{i}
$$

where $i$ indexes plants; Output is measured by the total value of shipments, deflated by industrylevel price index; Payroll is the total salaries and wages: 10 and Capital is the value of the capital stock at the beginning of the year. The ASM stops surveying plants' capital stocks from 1988. For years subsequent to 1988, I compute capital stock by taking the previous census year's capital stock, adding up reported capital expenditures year by year, and depreciating using the industry-wide investment

\footnotetext{
${ }^{10}$ Payroll can also proxy for the quality of the work force. The results are unaffected if I use the total number of workers or plant hours.
} 
deflators in the NBER-CES Productivity Database11 Material is the sum of the cost of materials, intermediate goods, energy, and electricity. TFP, the residual from the above estimation, compares the actual amount of output a plant produces with a predicted amount of output. The predicted output is what the plant is expected to produce given the amount of inputs it uses. Because coefficients on capital, labor, and material inputs vary by industry and year, this specification allows for different factor intensities in different industries. The TFP can be interpreted as the efficiency measure of a plant relative to other plants in that same industry in a given year.

Because the estimation of TFP measure requires a particular functional form, I also examine two additional measures of performance: profit margin (used in Maksimovic, Phillips, and Prabhala, 2008) and return to capital (used in Bertrand and Mullainathan, 2003). I divide the gross profit by the value of shipments to construct profit margin and by capital stock to derive return to capital. The gross profit is calculated as the value of shipments net of total payroll and material costs.

\subsection{Descriptive Statistics}

Table 2 reports summary statistics for several key variables for the target firms and plants across seven years around the merger. The top panel presents the firm-level characteristics. A substantial sample attrition can be seen from the second column of the table. For instance, for the year immediately prior to the merger, denoted as T-1, I am able to match 1,430 target firms; however, only 1,305 of these firms exist the year when the merger is completed (T) and 1,275 exist one year after that $(\mathrm{T}+1)$. This means that for 155 mergers, I cannot find any plant left in ASM/CMF at T+1 that was originally owned by the target firm. The plant counts shown in column 2 in the bottom panel reflect this attrition. For example, of all 11,129 plants in T-1, less than 70 percent remain in the sample three years after the merger. On average, the acquired firms own about 8 plants prior to the merger and a little less than 7 three years after being acquired. This sample attrition confirms what Maksimovic, Phillips, and Prabhala (2008) find: Acquirers close 19 percent of acquired plants within three years of acquisition.

Mean and standard deviation for the number of employees and value of output are also reported. Two opposing trends can be observed in employment and output levels. While the employment level gradually declines from $\mathrm{T}-3$ to $\mathrm{T}+3$, output experiences a steady increase during the same period, both at the firm and the plant level, which seems to suggest that labor productivity is rising. The sample mean of total factor productivity peaks at $\mathrm{T}-3$, but deteriorates in the three-year span until reaching the trough at $\mathrm{T}$. It then improves from $\mathrm{T}+1$ to $\mathrm{T}+2$, although the highest post-takeover level

\footnotetext{
${ }^{11}$ Available at http://www.nber.org/nberces/
} 
$\mathrm{T}+2$ is still slightly lower than $\mathrm{T}-3$. This trend of productivity changes is consistent with Yang's (2008) finding that deterioration in productivity precipitates asset sales.

\subsection{Control Sample}

The first goal of this paper is to estimate the effect of takeovers on target plants' productive efficiency. Acquirers do not choose target firms at random, which leads to a selection bias problem. Changes between pre-merger and post-merger depend on a variety of economy and/or industry factors such technology/demand shocks, or on a continuation of firm-specific performance trend. When a target firm experiences a 5 percent productivity gain post-takeover, the interpretation depends on whether comparable firms grow by 3 percent or shrink by 10 percent during the same period. Therefore, it is important to select a control group close to the counterfactuals as benchmarks. My approach here is to choose a group of comparable plants for each target plant based on industry, size, and productivity one year prior to the takeover year. Once I identify the control plants, I use the permanent plant identifier to follow them before and after the merger year the same way that I track the "actual" target plants. The procedure I used is the following:

(1) I begin with all plants available at ASM/CMF and create three equally-sized groups according to the total number of employees (large, medium, and small plants) within each three-digit SIC industry.

(2) In the year immediately before the takeover (T-1), I sort TFP within each SIC-size cell. From the pool of plants that are not acquired the following year, I retain two plants immediately higher and two immediately lower in TFP than a target plant. By construction, each target plant has at most four control plants.

(3) After identifying all the control plants at T-1, I follow these control plants backward at T-3 and $\mathrm{T}-2$, and forward at $\mathrm{T}, \mathrm{T}+1, \mathrm{~T}+2$, and $\mathrm{T}+3$.

Several observations lead me to adopt the above dimension-by-dimension matching method when constructing my control group 12 I choose to match on plant-level characteristics because later I focus on plant-level productivity and related outcomes. I first match on three-digit SIC industry. Mergers are clustered in industries undergoing exogenous shocks (Mitchell and Mulherin, 1996); thus, the industry-year distribution of the target firms is not random. It is more useful to compare productivity levels within a given industry. Previous studies on post-merger performance often choose industry median for convenient reasons. Harford (2005), however, discounts the validity of this approach. He asserts that due to changes an industry is undergoing and the endogeneity of the choice to merge, the

\footnotetext{
${ }^{12} \mathrm{An}$ alternative is to use propensity score matching. One issue here is data snooping as the quality of model fit for target selection is poor. Jensen and Ruback (1983, p. 29) stated that "it is difficult, if not impossible, for the market to identify future target firms." See Li and Prabhala (2007) for a detailed assessment of the matching techniques.
} 
contemporaneous performance of industry median firm is a problematic proxy. I next match plants by size. A plant chooses an optimal size given its productivity; hence, productivity distributions depend on size. I last select control plants that are closest to a target plant in terms of TFP within each SIC-size cell. This is similar to the spirit of Barber and Lyon (1996) on constructing control firms based on comparable pre-event performance. Matching the productivity leve ${ }^{13}$ immediately before the merger allows me to compare productivity outcomes for targets relative to a group of most-similar non-target counterparts. This way, I am able to test hypotheses $\mathbf{H 1}$ versus H1a more stringently. To check the robustness of the results, In Section 4.4, I also experiment with another group of control plants matched by industry, age, and size. In Section 4.5, I use unsuccessful mergers as counterfactuals for how the successful takeovers would have affected productivity thereafter.

\section{The Real Effects of Takeovers}

\subsection{Effects on Productive Efficiency}

To compare the productivity outcomes of target plants relative to controls subsequent to a takeover, I perform a differences-in-differences analysis for target and control plants in an unbalanced six-year panel 14

$$
Y_{i t}=\alpha+\beta_{1} \text { After }_{t}+\beta_{2}\left(\text { After }_{t} * \text { Target }_{i}\right)+\text { Plant } \mathrm{FE}+\text { Year FE }+\epsilon_{i t}
$$

In the above equation, the dependent variable Y includes TFP, profit margin, and return to capital. After is a dummy variable equal to one for $\mathrm{T}+1, \mathrm{~T}+2$, and $\mathrm{T}+3$ and zero otherwise. Target is a dummy variable that equals one if the target plant's parent firm is acquired at $\mathrm{T}$ and zero for control plants. I also use plant size, measured by the logarithm of total number of employees, as a control variable in some specifications as a robustness check. I only include plants that have at least one observation both before and after the event in the analysis. The above research design is similar to a program evaluation regression labor economists often use. The target plants belong to the "treatment" group; the comparable plants not acquired belong to the "control" group; and the "treatment" event is a "takeover." In essence, I am evaluating the effect of takeover by comparing the before-andafter outcome changes of the treatment group with that of the control group. The coefficient on the interaction term After* Target can be interpreted as the difference in productivity growth for targets

\footnotetext{
${ }^{13}$ Yang (2008) shows that productivity changes, rather than levels, affect the probability of plant sales. I also find that target plants' total factor productivity declines before mergers. I run a simple regression $\mathrm{TFP}_{\mathrm{T}-1}-\mathrm{TFP}_{\mathrm{T}-3}=$ $\alpha+\beta$ Target + Industry $\mathrm{FE}+$ Year $\mathrm{FE}+\epsilon$ and find that $\beta$ is statistically indistinguishable from zero. This means that pre-takeover TFP growth was not systematically higher for target plants, thus dispelling the concern that pre-existing trend in TFP drives the results. Results are available from the author upon request.

${ }^{14} \mathrm{I}$ drop year $\mathrm{T}$ (the merger completion year) to have a more balanced sample for before-and-after analysis.
} 
relative to control plants between three years before and three years after the merger. The standard errors are clustered at the firm level to allow for group effects within a firm.

The resulting differences-in-differences estimates are presented in Table 3. As can be seen from the first two columns, the coefficient $\beta_{2}$ on the interaction term is positive and statistically significant at the 1 percent level. This indicates target plants exhibit higher growth in TFP than controls. On average, three years after a merger, the acquired plants accomplish a 1.1 percentage points TFP growth premium relative to controls. This figure is comparable to what the prior literature has found. For example, Schoar (2002) reports a 0.4 percent increase and Maksimovic and Phillips (2001) report a 2 percent increase in industry-adjusted TFP three years following a takeover. Columns 3 to 6 of Table 3 use Profit margin and Return to capital to examine the impact of the takeover on target plants' profitability. As they turn out, $\beta_{2}$ are positive for both dependent variables, indicating that an increase in productivity also improves a plant's profitability. Profit margin experiences a modest increase by 0.4 percentage points. Return to capital sees a substantial increase; the target plants experience a 25 percentage points higher growth rate relative to controls. After controlling for plant fixed effect, the plant size is negatively associated with productivity.

The negative coefficient on After indicates that productivity and profitability of the control plants decline after the target plants are acquired. I offer two conjectures to explain this finding. First, Mitchell and Mulherin (1996) and Harford (2005) find that merger and restructuring activities clustered within industries in response to major deregulation or technological shocks. Such shocks might lead to worsening performance for plants that do not react accordingly. Second, TFP measures a plant's efficiency relative to its industry peers. If target plants experience improvements in TFP, controls plants in the same industry are more likely to experience performance declines due to competitive pressures.

\subsection{Effects on Outputs and Inputs}

I next explore the detailed mechanisms through which the acquiring firms improve the target plants' TFP. I do so by breaking down TFP into output and input components and estimate the impact of takeovers on these components separately within the same differences-in-differences framework.

Table 4 reports the estimation results. All the dependent variables shown are in logarithms. In the top panel, the coefficients on the interaction term are negative and statistically significant for all outcome variables except for output. These results suggest that, post-takeover, target plants produce 0.2 percent less output than the controls, but such a difference is statistically indistinguishable from zero. Target plants' investments, as measured by capital expenditures, experience steep declines. 
Three years following a takeover, a target plant's capital expenditures are about 13 percent less than those of controls. These cutbacks can potentially improve productive efficiency for two reasons. First, merging firms can eliminate duplicate investments and create a more efficient internal capital market. Second, previous investments may be wasted on unprofitable projects that destroy firm value. These two aspects give the acquiring firms an opportunity to scale back capital expenditures while enhancing efficiency. The material costs dip by 0.9 percent in comparison to the control group. Column 3 and 4 report results on wage and employment changes. Average annual wage per worker drops by about 0.5 percent and employment level by about 2.3 percent more than those of the controls. This finding is in disagreement with the hope that the acquiring firms could share some of the productivity gains with their new employees 15 Instead, target firm's employees are adversely affected by the takeovers.

I also look at wage and employment outcomes separately for two groups of workers: productionworkers and non-production workers. Note that non-production workers in my context are those who work inside a plant. I do not have information regarding non-production workers employed at the headquarters or other non-manufacturing establishments such as sales or distribution centers. The real effects on non-production workers, therefore, are probably under-estimated. As seen in the bottom panel of Table 4, while average wages for the two groups experience minimal declines, the reduction in jobs is greater in target plants, especially among non-production workers. On average, production workers are cut by about 1 percent more while non-production workers are cut by almost 5 percent more compared with controls. This finding is consistent with Jensen and Ruback's (1983) view that the market for corporate control is an important component of the managerial labor market. Takeovers create competition for the right to manage resources and achieve efficiency by replacing the target firms' management teams.

The above results show that TFP improvements result from the acquiring firm's more efficient use of various production inputs. Post-takeover, target plants are able to produce the same level of output relative to control plants, but to do so by using less investment and material, offering lower wages, and hiring fewer workers. Back of the envelope calculations reveal that 70 percent of the TFP improvements result from cutbacks in payroll and the remaining 30 percent result from cutbacks in capital expenditures and material costs. These results offer support for H2, that is, acquirers improve targets' productive efficiency through restructuring and downsizing.

\footnotetext{
${ }^{15}$ For instance, Schoar (2002) shows that diversified firms have higher productivity but lower equity value because they dissipate rents by offering higher wages.
} 


\subsection{Effects on Plant Closure}

The above estimations rely on information from continuing plants. The target firm's overall efficiency can be improved upon mainly through two channels. First, the acquiring firms can revamp existing plants' operations to make them perform better. Second, they can selectively shut down underperforming plants. To shed light on this selection channel, I compare the plant exit probability between target plants and control plants each year at $\mathrm{T}, \mathrm{T}+1, \mathrm{~T}+2, \mathrm{~T}+3$, and then cumulatively from $\mathrm{T}$ to $\mathrm{T}+3$. Plants may exit the ASM sample over time, however, through panel rotation. To accurately characterize plant death, I draw information from the Longitudinal Business Database (LBD), also maintained at the Census Bureau. The LBD covers all U.S. establishments and firms with at least one paid employee from 1976 to 2005. It is constructed from the Business Register and enhanced with various survey data collections. ${ }^{16}$ In recent years, it has contained more than 6 million establishment records and almost 5 million firm records per year. The LBD contains basic establishment level information including payroll, employment, and first/last year of operation. I use the LBDNUM to match ASM/CMF plants with establishments in LBD to obtain their last year of operation. I code the exit year for all the target and control plants at $\mathrm{T}-1$, and define an indicator variable that equals one if the last year of operation of that particular plant is recorded at $\mathrm{T}, \mathrm{T}+1, \mathrm{~T}+2$, or $\mathrm{T}+3$ and zero otherwise. For example, in 1987, a plant that was to be acquired in 1988, had the last year recoded in LBD as 1990, then the exit dummy variable equals one for period $\mathrm{T}+2$.

I estimate an exit probability model for a pooled sample of the target and control plants at $\mathrm{T}$, $\mathrm{T}+1, \mathrm{~T}+2$, and $\mathrm{T}+3$, respectively, and then cumulatively from $\mathrm{T}$ to $\mathrm{T}+3$. I control for a plant's initial size and TFP as well as industry and year fixed effects:

$$
\operatorname{EXIT}_{i t}=\alpha+\beta_{1} \text { Target }_{i}+\beta_{2} \text { TFP }_{i}+\beta_{3}\left(\text { TFP }^{*} \text { Target }_{i}\right)+\text { Industry FE }+ \text { Year FE }+\epsilon_{i t}
$$

Due to the presence of a large number of fixed effects, I mainly use linear probability model to estimate Equation (7) but use probit model to estimate the cumulative exit probability between $\mathrm{T}$ and $\mathrm{T}+3$. Results in Table 5 show that the target plants are more likely than controls to be shut down each year following the merger. The coefficient on Target captures the difference in exit probability between a target plant and a control plant. At the year when the merger is completed, a target plant is 0.5 percentage points more likely to cease operation. This difference jumps to 2.2 in the first two years and then drops to 1.6 percentage points the third year following the takeover. The last column reports the marginal effects from a probit model. Cumulatively, three years following a takeover, a

\footnotetext{
${ }^{16}$ See Jarmin and Miranda (2002) for a detailed description of the LBD.
} 
target plant is 6.9 percentage points more likely to be close than control plants. Not surprisingly, smaller plants and plants with lower productivity are more likely to be shut down.

To examine further whether the acquiring firms are more likely to close less productive plants, I interact the dummy variable Target with TFP. Except for year T+3, the coefficient on this interaction term is negative and statistically significant. This implies that acquiring firms are not only more aggressive in shutting down plants, but also in shutting down inefficient plants. My results complement the conclusions in Maksimovic, Phillips, and Prabhala (2008) who show that acquirers tend to discard the target's assets in their peripheral divisions. Here, I show that acquirers shed less-efficient target plants more expediently.

As one can see from results in Section 4.2 and Section 4.3, target plants undergo more intense restructuring than otherwise-similar plants. The acquiring firm restructures the target by cutting back investments and labor within continuing plants and by shutting down more inefficient plants. Therefore, $\mathbf{H 2}$ is supported: The acquiring firm achieves productive efficiency improvements through restructuring the target firm. The restructuring activities include employee layoffs, wage reductions, investment cutbacks, and plant closures.

\subsection{Robustness Checks}

In this section, I check the robustness of the above results by performing two additional tests. First, I use a different control sample to mitigate the concern that the above results are an artifact of a particular control sample. Second, I utilize a small sample of mergers that are ultimately withdrawn by acquirers to conduct a placebo test.

\subsubsection{A Different Control Sample}

I construct a different sample of control plants by matching on industry, age cohorts, and total number of employees pre-takeover following Davis et al. (2008). Specifically, I create three equally-sized age groups (young, middle-aged, and old) within each three-digit SIC industry. In the year prior to the takeover, I sort the total number of employees with each SIC-age cell and retain two plants immediately larger and two immediately smaller than the targeted plant to form my control groups. The number of observations in this alternate control group is slightly greater than the previous control sample because more values are missing for TFP than for the total number of employees.

I perform the same differences-in-differences estimations using this new group of control plants. Results in Table 6 are generally consistent with those shown in Table 3. The TFP growth premium of target plants over this new sample of control plants is about 1 percentage points, compared with the 
1.1 percentage points in Table 3; Profit margin grows by one-tenth of a percentage point faster than the controls, but this figure is not significantly different from zero at the conventional statistical level; Return to capital undergoes substantial improvement by about 17 percentage points, compared to the point estimate of 25 in Table 3. The results for other variables in Table 6 are similar to those reported in Table 3.

Table 7 presents the differences-in-differences estimates for all the output and input components. Similarly, all inputs decline relative to controls. Capital expenditures decline by about 11 percent more than the controls; Wage rate drops by nearly 1 and employment level by about 2 percent more than controls. When I break down wage and employment outcomes for production and non-production worker groups, the only variable that drops significantly more relative to the controls is the nonproduction workers' employment level. As one can see, point estimates and standard errors are very similar between Table 4 and Table 7 . This result confirms that the previous estimates are robust to the control sample selections.

\subsubsection{A Placebo Test with Unsuccessful Mergers}

Several recent studies (e.g., Pavel and Lu, 2009; Seru, 2010) use mergers that fail to consummate to identify the treatment effect of takeovers. I follow their approach and identify 236 target firms that bidders ultimately withdraw from acquiring. The sample of unsuccessful mergers allows me to perform two tests. First, I use these unsuccessful targets as counterfactuals for how the successful targets would have affected productivity after mergers. In particular, I perform a differences-in-differences regression using these unsuccessful target firms as a new control sample. The results (unreported) show that relative to these unsuccessful targets, target plants exhibit a 1.5 percentage points gain in TFP posttakeover. In addition, I conduct a "placebo" test to examine whether these unsuccessful takeovers improve their potential target plants' TFP. The results (unreported) show that unsuccessful takeovers fail to increase their potential target plants' productivity relative to comparable control plants. This finding further supports that takeover improve productivity through the actual change of ownership rather than potential threats by announcements.

In summary, these results consistently show that target plants experience about 1 to 1.5 percentage points net productivity gains over control plants. Capital expenditures experience significant decline, by about 10 to 12 percent, compared with controls. Employees seem to fare worse after takeovers. Average wage and employment are lowered by about 1 to 2 percent relative to controls, respectively. The employment cuts are mostly concentrated among non-production workers whereas production workers are largely unaffected. 


\subsection{Acquirers' Incumbent Plants}

While the focus of this paper is target plants after a takeover, a related question is how the acquisition affects acquirers' incumbent plant. Only a small portion of the acquiring firms can be matched to ASM/CMF. Of the 1,430 targeted firms, 770 of them are acquired by another U.S. publicly-listed firm. Among these acquiring firms, only about 500 of them can be matched to ASM/CMF. Some of these acquiring firms are repeated acquirers within a few years, which creates difficulty for me to assign "before" and "after" based on an acquisition event. Solely examining first-time acquirers or acquisitions made some distant apart over time might not provide a complete picture of how acquisitions affect the acquiring firms' incumbent plants. Nevertheless, based on a restricted sample, I find that acquisitions seem to have negligible effects on the acquirers' incumbent plants, either on productivity or on various types of inputs. I do not report the results here in order to conserve space.

\section{Determinants of Announcement Returns}

The above results show that target plants exhibit net improvements in total factor productivity and net losses in wages and employment. In this section, I analyze the relation between what happens within the target firm and what happens in the stock market when the merger is announced. In particular, I explore the cross-sectional differences in merger announcement returns from the perspective of the target firm's gains in productivity and losses in wages and employment. To pursue this, I augment the standard regressions of announcement returns with the target firm's change in TFP and payroll between $\mathrm{T}-1$ and $\mathrm{T}+1$. The specification is as follows:

$$
\text { Combined } \mathrm{CAR}_{(-1,+1)}=\alpha+\beta_{1} \Delta \mathrm{TFP}+\beta_{2} \Delta \text { Payroll }+X \gamma+\epsilon
$$

In Equation (8), the dependent variable is the three-day combined cumulative abnormal return (CAR) for the target and the acquiring firm. CAR is estimated using a market model estimated over the $(-205,-6)$ interval. Combined CAR is calculated as the equity weighted sum of target CAR and acquirer CAR following the method suggested by Bradley, Desai, and Kim (1988). The combined announcement returns measure the total surplus to shareholders generated by the merger. Later, I also consider offer premiums to the target and the returns to acquirer separately using the same specification.

$\triangle \mathrm{TFP}$ is calculated by subtracting the target firm's TFP at $\mathrm{T}-1$ from TFP at $\mathrm{T}+1 . \Delta$ Payroll measures the target firm's percentage change in total payroll. I calculate $\Delta$ Payroll by subtracting the 
logarithm of Payroll at T-1 from the logarithm of Payroll at T+1. The firm's TFP and Payroll are formed as the employment-weighted average of all the active plants' TFP and payroll, respectively. This method of construction is designed to capture two aspects of changes: The improvement effects over the continuing plants and the selection effects of closing failing plants. Note that only target firms with at least one plant active at both $\mathrm{T}-1$ and $\mathrm{T}+1$ are included in the sample. Table 8 reports the mean, standard deviation, and pairwise correlation for some variables of interest. Among the 1,430 merger transactions, 1,226 target firms have non-missing values on $\Delta \mathrm{TFP}$ and $\Delta$ Payroll; and 660 target firms are acquired by another publicly-listed firms with information available from CRSP. On average, TFP increases by 1.1 percent and total payroll decreases by about 5 percent in the target firm over two years. $\triangle \mathrm{TFP}$ and $\triangle$ Payroll are negatively correlated with each other. According to the pairwise correlation, $\triangle \mathrm{TFP}$ is positively correlated with combined CAR and offer premiums but negatively correlated with acquirer $\mathrm{CAR}$, while $\Delta$ Payroll is positively correlated with all three return variables.

Several choices of variables are worthy of further explanation. First of all, one would also want to incorporate changes to the acquiring firm into the estimation. I focus solely on changes to the target firm's plants due to two considerations. On the one hand, prior literature and my results both reveal that target firm's plants undergo much more restructuring than the acquiring firms' incumbent plants following an acquisition. The unreported results referenced in Section 4.5 show that the acquiring firm's incumbents plant are generally unaffected by the acquisition. On the other, as also stated in section 4.5 , only a small subset of the targets are acquired by another firm that can be matched to ASM/CMF, and CRSP and many of these matches are repeated acquirers (within a few years). Incorporating the changes to the acquiring firm's incumbent plants will reduce the sample size unnecessarily. Second, I only consider the changes that occurred between $\mathrm{T}-1$ and $\mathrm{T}+1$. This is likely conservative because some of the changes in productivity and payroll may appear later. Yet changes between these three years still capture much of the action due to the merger. Last, the announcement returns reflect expectations of future economic gains or losses; hence, all the analysis hinges on the assumption that the market expectation is eventually realized.

To explore other determinants of announcement returns, I mainly consider two groups of factors: Target/acquirer firm characteristics and deal characteristics. The firm characteristics include firm size and the market-to-book ratio. Both variable are measured at the fiscal year prior to the takeover announcement. I also create a relative size measure for the target, calculated as the share of the target firm's market value to the sum of the target and the acquirer's market value, as used in Hoberg and Phillips (2010). 
Deal characteristics include offer premium, method of payment, target-acquirer industry relatedness, and acquirer's listing status. I calculate the premium as the ratio of deal value to the target's market value 30 days before the merger announcement. I create two variables All Cash and Some Stock to distinguish between mergers financed by cash versus stock. I measure target-acquirer relatedness using a dummy variable that equals one if the target and the acquirer share the same primary two-digit SIC industry. I also consider the listing status of the acquiring firm. I create an indicator variable Private Acquirer which equals one if the acquiring firm is not publicly-listed, and zero otherwise. A detailed description of the variables is provided in Appendix A.

I estimate Equation (8) to test the efficiency creation hypothesis and the employee wealth redistribution hypothesis. The hypothesis that the total gains to shareholders reflect efficiency improvements implies $\beta_{1}$ is positive. Alternatively, if the total gains represent wealth redistribution from the target firm's employees, $\beta_{2}$ should be negative.

\subsection{Effects of Changes in Productivity and Payroll on Combined CAR}

Table 9 reports estimates from cross-sectional OLS regression of the combined CAR. Odd-numbered columns control only for deal characteristics, while even-numbered columns also control for the acquirer's characteristics and therefore have a smaller number of observations. Point estimates and standard errors across the two specifications are very similar. The coefficients on $\triangle \mathrm{TFP}$ in the first two columns are positive and statistically significant, which suggests improvements in productivity are associated with higher combined CAR. In terms of economic significance, the coefficient of 0.039 in column 2 implies that acquiring a target firm with $\triangle \mathrm{TFP}$ at the 25 th percentile yields 1 percentage points lower combined announcement returns than acquiring a target with $\Delta \mathrm{TFP}$ at the 75 th percentile in my sample. This amount is considerable given that the sample median of the combined CAR is less than 3.5 percent. Results in columns 3 and 4 show that changes in the target firm's total payroll are not significantly related to the combined CAR. When I control for both $\triangle \mathrm{TFP}$ and $\Delta$ Payroll in columns 5 and 6 , the results on $\triangle \mathrm{TFP}$ remain similar to those in columns 1 and 2 , and the coefficients on $\Delta$ Payroll are again statistically indistinguishable from zero. These results provide support for $\mathbf{H 3}$ rather than $\mathbf{H 4}$; that is, improvements in productivity rather than wealth redistribution from employees are associated with higher combined firms' announcement returns. In columns 7 and 8 , I further add the interaction terms of relative size of target (RelaSize) with $\triangle T F P$ and $\Delta$ Payroll. The idea is that some of the improvements in TFP or labor costs savings in the target firm might not affect the combined returns because the targets are very small relative to the acquiring firm. The results show that both the coefficients on RelaSize and the interaction terms between $\triangle \mathrm{TFP}$ and RelaSize 
are positive and statistically significant at the 1 percent level. This indicates that the positive effect of $\triangle \mathrm{TFP}$ on combined CAR is magnified when target is relatively larger compared with acquirer. Ceteris paribus, if the target's pre-takeover market value is half of the acquirer's, an acquisition of a target firm with $\triangle \mathrm{TFP}$ at the 25 th percentile yields about 2.5 percentage points lower total announcement returns than a target with $\triangle \mathrm{TFP}$ at the 75 th percentile. Also worth noting is the fact that the $\mathrm{R}^{2}$ in these two specifications increases from about 10 percent to about 30 percent when I control for all the covariates. These results further support the prior finding that improvements in productivity underlie the wealth gains to the combined firms' shareholders.

Results on other control variables are generally consistent with findings in prior literature. Related mergers generate about 2 percentage points higher combined returns than unrelated mergers. If the acquirer uses some stocks to pay for the target, the combined returns are lowered by about 3 to 4 percentage points. Large acquiring firms tend to make value-destroying acquisitions, as shown in Moeller, Schlingemann, and Stulz (2004, 2005). Prior studies find that the Tobin's Q (the close surrogate of market-to-book ratio) has an ambiguous effect on merging firms' announcement returns. For instance, Lang, Stulz, and Walkling (1989) and Servaes (1991) find that combined CAR are positively related to the acquirer's Q, while Moeller, Schlingemann, and Stulz (2004) show the contrary. In my sample, I find that the acquirers with higher market-to-book ratio are associated with negative announcement returns for the combined firm.

\subsection{Effects of Changes in Productivity and Payroll on Offer Premium}

I next estimate the same regression of offer premium on improvements in TFP to test $\mathbf{H 5}$, that is, whether offer premiums can be explained by post-takeover productivity improvements. The results are presented in Table 10. The coefficient on $\triangle \mathrm{TFP}$ is positive and statistically significant, which suggests that the acquiring firm does pay a higher premium to a target with greater post-takeover improvements in productivity. Point estimates on $\triangle \mathrm{TFP}$ range from 0.25 to 0.38 depending on different sets of control variables. To interpret the economic magnitude, other things being equal, a target at the 25 th percentile of $\triangle \mathrm{TFP}$ receives about 6 to 9.5 percentage points lower premium than a target at the 75 th percentile. Such a change is substantial considering that the median value of the offer premium in my sample is about 50 percent. The statistical insignificance of the coefficient on $\Delta$ Payroll suggests that variations in changes in payroll do not explain variations in offer premium. Hence, $\mathbf{H 5}$ is supported: Cross-sectionally, target firms with greater post-takeover improvements in productivity receive higher offer premiums from the acquirer. This results are consistent with insights from Rhodes-Kropf and Robinson (2008) who posit that the bargaining outcome of merger depends on merging firms' expected 
gains from waiting, which in part are determined by the expected surplus from future transactions. To the extent that targets with greater productivity improvements are also expected to gain more from merging with other firms, they are in a stronger bargain position to demand for higher premiums from acquirers.

Baker, Pan, and Wurgler (2010) recently advance a "reference point" explanation arguing that acquirer's offer prices are benchmarked against target's previous 52-week highest price. In columns 5 to 8, I further include a control variable for target's 52-W High Price, which has a positive and statistically significant effect on offer premiums. This supports the conclusions in Baker et al. (2010). After controlling for the 52-W High Price, the results on $\triangle \mathrm{TFP}$ are actually strengthened. The point estimates on $\triangle \mathrm{TFP}$ become greater and are statistically significant at the 5 percent level. Much of the explanatory power comes from a few variables related to the deal's characteristics. A target that shares the same primary industry with the acquiring firm receives a 30 percentage points higher premium from an acquirer; the target is willing to trade for a significantly lower premium for cash payment. Consistent with Bargeon, Schlingemann, Stulz, and Zutter (2008), a private acquiring firm pays a lower premium than a public acquirer. Regression results on the target's CAR are generally similar to results on offer premiums. For space considerations, I do not report those results here.

\subsection{Effects of Changes in Productivity and Payroll on Acquirer's CAR}

Last, I look at the acquiring firm's announcement returns. The results are reported in Table 11. $\Delta \mathrm{TFP}$ has a positive effect on the acquirer's CAR although the point estimate is not statistically significant at a conventional level. In fact, very few regressors have significant explanatory power for the acquirer's CAR. The two exceptions are variables for stock mergers and the acquirer's size. Both variables are negatively associated with acquirer's CAR, which are consistent with the stylized facts documented in Moeller, Schlingemann, and Stulz (2004, 2005). Mergers with large acquirer and mergers financed by acquirer's stocks are bad news for the acquiring firm's shareholders. As shown in the last two columns, I also control for the interaction term between the target's relative size and $\triangle$ TFP. In column 8 , the coefficient on the interaction term is 0.116 , statistically significant at the 5 percent level. The point estimates reveal that if the target is half the size of the acquirer, acquiring a target at the 25th percentile of $\triangle \mathrm{TFP}$ generates about 2 percentage points higher than acquiring a target at the 75 th percentile. The magnitude of the increase is economically significant as the sample mean of the acquirer CAR is merely zero.

The general absence of significance for the acquirer's CAR is perhaps not surprising. Prior literature has offered several explanations (see Houston, James, and Ryngaert (2001) for details). Two 
explanations are particularly relevant. First, on average, the acquiring firms are much larger than the target; therefore, improvements over the target firms might not lead to discernable gains to the acquiring firms themselves. Second, my prior results on offer premium suggests that the joint gains are captured mostly by the target firm's shareholders as evidenced in the lofty offer premiums.

\subsection{Further Tests of the Employee Wealth Redistribution Hypothesis}

Though prior results consistently show that labor cost cuts in employees' total payroll are not associated with merging firms' announcement returns, it is still premature to dismiss wealth redistribution from employees as a possible explanation for shareholder gains. The empirical challenge is that wage and employment reductions are probably part of the productivity-increasing process; therefore, one cannot separately identify the effect of employee redistribution on shareholders value gains. In this section, I conduct two additional tests to disentangle the efficiency creation hypothesis from the employee wealth redistribution hypothesis.

First, I regress dollar value gains to shareholders (based on premiums and combined CAR) on dollar value savings from employee payroll. The results are reported in Table 12. The first three columns report results where I use Dollar Premium as measures for gains to the target firm's shareholders. The point estimates of $\Delta$ Dollar Payroll are less than -1 and are statistically significant. The coefficient implies that a $\$ 1$ cut to employee payroll translates to $\$ 1.97$ to $\$ 5.80$ dollar gain to the target firm's shareholders ${ }^{17}$ This result is partly consistent with the stakeholder view of the firm: Shareholders hold the residual claim value of the firm, whereas the employees receive contractual compensation for their services. Abowd (1989) finds that unexpected increases in collectively bargained labor costs lead to a dollar-for-dollar decrease in a firm's equity values. My finding that the point estimate is greater than one seems to suggest savings from labor costs not only transfer the saved amount but also entail additional value transfers — possibly through productivity gains — to shareholders. Columns 4 through 6 report estimates when I use dollar gains to the combined firm as dependent variables. Point estimates of coefficients on $\Delta$ Dollar Payroll are negative although statistically indistinguishable from zero.

Second, I examine the employee wealth redistribution hypothesis from the perspective of changes in fringe benefits. Employees' fringe benefits include pension plans, health insurance, and unemployment benefits etc. Different from Payroll, which is directly factored into construction of the TFP measure (see Equation (5)), the costs of fringe benefits are not. I re-estimate the Equation (8) adding per-

\footnotetext{
${ }^{17}$ The dollar gains to shareholders are significantly greater than dollar savings in payroll in absolute amount. This might explain why I do not find significant relation between $\Delta$ Payroll and combined CAR.
} 
centage change in target's cost of fringe benefits $\Delta$ Fringe Benefits. Regression results are reported in columns 1,3 , and 5 of Table 13 . Point estimates on $\Delta$ Fringe Benefits indicate that changes in the cost of fringe benefits are not associated with combined CAR, offer premium, or the acquirer CAR. Furthermore, a firm's payroll is a product of the average employee wage and the total number of employees. I then investigate whether employee wealth redistribution can arise separately from reductions in wage and/or employment. Employee wealth redistribution can nonetheless occur at individual level (through employee layoff), or at the group level (through wage reduction). Columns 2, 4, and 6 report estimates when I regress announcement returns on $\Delta$ Wage Rate and $\Delta$ Employment. Neither of these two variables, however, are statistically significantly related to the merging firms' announcement returns. These results show that cuts in employees' fringe benefits, average employee wage, and total employment level cannot explain gains to shareholders. Again, these findings do not support the employee wealth redistribution hypothesis.

In summary, these two additional tests provide further evidence that the extent of employee wealth redistribution is relatively small. They reinforce the conclusion that improvements in productivity, rather than wealth redistribution from employees, underpin the wealth gains to the shareholders of the merging firms.

\section{Conclusions}

In this paper, I attempt to uncover the underlying sources of gains from takeovers. I tackle this question in two steps. First, by examining changes to output, input, and plant closures after a takeover, I identify the detailed channels through which the acquiring firm enhances the target firm's productivity. Second, by establishing a direct relation between a target firm's underlying gains and losses and takeover announcement stock returns, I provide some micro-foundations to understand the stock market revaluation of the merging firms.

I analyze a sample of 1,430 mergers using plant-level data from the U.S. Census Bureau. To evaluate the real effects of takeovers, I construct a group of control plants that are comparable to target plants in terms of industry, size, and productivity as benchmarks. Using a differences-in-differences regression approach, I find that target plants exhibit net gains in total factor productivity, profit margin, and return to capital, relative to comparable plants. These improvements are accomplished mainly through two avenues. First, the acquiring firm is able to deploy the resources more efficiently. In particular, while the target plants undergo significant cutbacks in capital expenditure, wages, and employment, the level of output remains largely unaffected, relative to controls. Second, the acquiring firms are 
more aggressive in shutting down the target plants, especially those that are less efficient.

These micro-level changes help explain the cross-sectional differences in merging firms' announcement returns. I consider the impact of the target firm's gains in productivity and savings in labor costs on announcement returns of the merging firms. I show that improvements in productivity, rather than savings on labor costs, are associated with higher combined announcement return for the target and acquiring firms. The effect of increase in productivity on combined announcement return is statistically robust and economically significant. This evidence provides support for the hypothesis that efficiency creation, rather than wealth redistribution from employees, underlies the total wealth gains to the shareholders.

When I examine the gains to the target and the acquirer separately, I find that the target firms with greater future improvements in productivity receive higher offer premiums from the acquiring firms. Neither improvements in productivity nor savings from labor costs, however, are significantly associated with the acquirer's own announcement returns. It remains an open question why the target shareholders capture most of the joint efficiency gains. A detailed examination of the division of the total gains is left for future research.

The potential for wealth redistribution from employees in the target firm has generated considerable controversy in public policy debates over mergers. My results provide strong support for the efficiencyenhancing aspect rather than the wealth redistribution aspect of mergers. Overall, my study shows that takeovers are an efficient mechanism to reallocate productive assets to management that can better use them. This study also highlights the interconnections between product market, labor market, and the stock market, in the context of mergers and acquisitions. 


\section{Appendix A: Variable Definitions}

\section{Variable}

$\mathrm{CAR}_{(-1,+1)}$

Total $\mathrm{CAR}_{(-1,+1)}$

Related

All Cash

Some Stock

Private Acquirer

Premium

Asset

Market-to-book ratio

RelaSize

52-W price high

Output

\section{Description}

Cumulative abnormal returns over three days surrounding the announcement calculated using a market model adjusted by the value-weighted CRSP market index. The parameters for the market model are estimated over the $(-205,-6)$ interval.

Weighted average of $\mathrm{CAR}_{(-1,+1)}$ for the acquirer and target, where the weight is the market value of the two firms three days before the announcement.

$=1$ if the target and the acquirer share the same primary two-digit SIC, 0 otherwise.

$=1$ if $100 \%$ of the transaction value was paid by cash, 0 otherwise.

$=1$ if at least some part of the transaction was paid by stock, 0 otherwise.

$=1$ if the acquiring firm is a not publicly-listed, 0 otherwise.

Transaction value recorded by SDC divided by the market value of the target 4 weeks before the announcement. Book value of book assets (item 6)

(Book value of asset - book value of equity + market value of equity)/Book value of assets.

Target's Market Value/(Target's Market Value + Acquirer's Market Value), where the market value three days before announcement is used.

Target's 52-week highest stock price divided by the target

CRSP price 30 days before the announcement.

Plant level output is total value of shipments, deflated to $\mathrm{ASM} / \mathrm{CMF}$ 1987 dollars using industry-specific price index from the NBER-CES Productivity Database.
Source

CRSP

CRSP

SDC

SDC

SDC

SDC

SDC

COMPUSTAT

COMPUSTAT

CRSP 
Investment

Material

Capital Stock

Payroll

Employment

Wage

Nonproduction Worker

Fringe Benefits
Plant level capital expenditure, deflated to 1987 dollars using industry-specific price index from the NBER-CES Productivity Database.

Sum of plant's expenditure on parts and intermediate goods, fuel, energy, electricity and contract work, deflated to 1987 dollars using industry-specific price index from the NBER-CES Productivity Database.

Total assets at the beginning of the year. In 1986 the ASM stopped collecting the book value of assets in noncensus years. For years since 1988, I employ recursive perpetual inventory formula using the nearest available book value of assets as the initial value. These values are written forward annually with nominal capital expenditure and depreciated with the economic depreciation rate at the industry level.

Total salaries and wages, expressed in 2005 US dollars. Total number of workers. Average annual wage per worker, expressed in 2005 US dollars.

Those engaged in "supervision above line - supervisor level, sales, advertising, clerical, and routine office functions".

Include health insurance, pension plans, and other bene-

$\mathrm{ASM} / \mathrm{CMF}$ fits.
ASM/CMF $\mathrm{ASM} / \mathrm{CMF}$ ASM/CMF

$\mathrm{ASM} / \mathrm{CMF}$

$\mathrm{ASM} / \mathrm{CMF}$

$\mathrm{ASM} / \mathrm{CMF}$

ASM/CMF 


\section{Appendix B: Sample Construction}

I provide detailed information on how I match the target firms in SDC to the ASM/CMF below. I match the target firm's CUSIP to the ASM/CMF's firm identifier (FIRMID) through a "COMPUSTAT-Standard Statistical Establishment List (SSEL) Bridge" file maintained by the Census Bureau. This bridge file is created by Steven J. Davis, John Haltiwanger, Ron Jarmin, and Javier Miranda (2006) "Volatility and Dispersion in Business Growth Rates: Publicly Traded versus Privately Held Firms." I also hand-match some of the unmatched target firms by matching firm name and address between SDC and SSEL, which is the Business Register data set of the U.S. Census Bureau. The overall matched cases represent over $70 \%$ of all mergers in my sample. The unmatched cases can be due to different definitions of parent firms, change in CUSIPs, and naming differences.

Firms in the Census are defined based on operational control, and all plants under the operational control of a parent firm share the same FIRMID. All the plants in the Census are assigned an invariant plant identifier "LBDNUM". The "LBDNUM" allows me to track the same target plants forwards and backwards in time. Firm identifiers can be broken primarily as a result of firm's merger and acquisition activity as well as expansions from single unit establishment entities to multi unit entities. Therefore, I match SDC to ASM/CMF the year before the merger completion year to obtain target firms' FIRMIDs and all the plants owned by the target firm.

Presumably, after an ownership change, the acquired plants' FIRMID would be replaced by the acquiring firm's FIRMID. However, the Census Bureau often fails to update this information in a timely manner to reflect such changes. This limitation makes it extremely difficult for me to trace accurately when and whether an acquired plant is sold to another firm (with a new FIRMID) after a takeovers. As a result, this study does not explicitly examines divestiture decisions.

I construct the sample of control plants based on three-digit SIC industry, total number of employ-

ees, and TFP. Note that from 1997, the Census Bureau adopts the NAICS industry definition. I use a concordance file provided by the Census Bureau to convert NAICS to 1987 SIC. 


\section{References}

Abowd, J. (1989). The effect of wage bargains on the stock market value of the firm. American Economic Review 79, 774-800.

Ahern, K. (2010). Bargaining power and industry dependence in mergers. Working paper, University of Michigan.

Andrade, G., M. Mitchell, and E. Stafford (2001). New evidence and perspectives on mergers. Journal of Economic Perspectives 15, 103-120.

Atanassov, J. and E. H. Kim (2009). Labor and corporate governance: International evidence from restructuring decisions. Journal of Finance 64, 341-374.

Baker, M., X. Pan, and J. Wurgler (2010). A reference point theory of mergers and acquisitions. Working paper, Harvard University and New York Unviersity.

Barber, B. M. and J. D. Lyon (1996). Detecting abnormal operating performance: The empirical power and specification of test statistics. Journal of Financial Economics 41, 359-400.

Bargeron, L. L., F. P. Schlingemann, R. M. Stulz, and C. J. Zutter (2008). Why do private acquirers pay so little compared with public acquirers? Journal of Financial Economics 89, 375-390.

Bates, T. H. and M. L. Lemmon (2003). Breaking up is hard to do? An analysis of termination fee provisions and merger outcomes. Journal of Financial Economics 69, 460-504.

Bertrand, M. and S. Mullainathan (2003). Enjoying the quiet life? Corporate governance and managerial preferences. Journal of Political Economy 111, 1043-1075.

Betton, S., B. E. Eckbo, and K. S. Thorburn (2008). Corporate takeovers. In B. E. Eckbo (Ed.), Handbook of Corporate Finance: Empirical Corporate Finance. Elsevier/North-Holland.

Bradley, M., A. Desai, and E. H. Kim (1988). Synergistic gains from corporate acquisitions and their division between the stockholders of target and acquiring firms. Journal of Financial Economics 21, $3-40$.

Brown, C. and J. L. Medoff (1988). The impact of firm acquisition on labor. In A. J. Auerbach (Ed.), Corporate Takeovers: Causes and Consequences. University of Chicago Press, Chicago.

Davis, S. J., J. Haltiwanger, R. Jarmin, J. Lerner, and J. Miranda (2008). Private equity, jobs, and productivity. Working paper, U.S. Census Bureau. 
Devos, E., P.-R. Kadapakkam, and S. Krishnamurthy (2009). How do mergers create value? A comparison of taxes, market power, and efficiency improvements as explanations for synergies. Review of Financial Studies 22, 1179-1211.

Ghosh, A. (2001). Does operating performance really improve following corporate acquisitions? Journal of Corporate Finance 7, 151-178.

Harford, J. (2005). What drives merger waves? Journal of Financial Economics 77, 529-560.

Hartzell, J. C., E. Ofek, and D. Yermack (2004). What's in it for me? ceos whose firms are acquired. Review of Financial Studies 17, 37-61.

Healy, P. M., K. G. Palepu, and R. S. Ruback (1992). Does corporate performance improve after mergers? Journal of Financial Economics 31, 135-175.

Hietala, P., S. N. Kaplan, and D. T. Robinson (2003). What is the price of hubris? Using takeover battles to infer overpayments and synergies. Financial Management 32, 5-31.

Hoberg, G. and G. Phillips (2010). Product market synergies and competition in mergers and acquisitions: A text-based analysis. Review of Financial Studies 23, 3773-3811.

Houston, J. F., C. M. James, and M. D. Ryngaert (2001). Where do merger gains come from? Bank mergers from the perspective of insiders and outsiders. Journal of Financial Economics 60, 285-331.

Jarmin, R. and J. Miranda (2002). The longitudinal business database. Working paper, U.S. Census Bureau.

Jensen, M. (1986). Agency costs of free-cash-flow, corporate finance, and takeovers. American Economic Review 76, 323-329.

Jensen, M. and R. S. Ruback (1983). The market for corporate control: The scientific evidence. Journal of Financial Economics 11, 5-50.

Kaplan, S. N. (1989). The effects of management buyouts on operating performance and value. Journal of Financial Economics 24, 217-254.

Kaplan, S. N. (2000). Introduction. In S. N. Kaplan (Ed.), Mergers and Productivity. University of Chicago Press, Chicago. 
Kaplan, S. N., M. L. Mitchell, and K. H. Wruck (2000). A clinical exploration of value creation and destruction in acquisitions: Organization design, incentives and internal capital markets. In S. N. Kaplan (Ed.), Mergers and Productivity. University of Chicago Press, Chicago.

Lang, L. H. P., R. M. Stulz, and R. A. Walkling (1989). Managerial performance, Tobin's Q, and the gains from successful tender offers. Journal of Financial Economics 24, 137-154.

Li, K. and N. R. Prabhala (2007). Self-selection models in corporate finance. In B. E. Eckbo (Ed.), Handbook of Corporate Finance: Empirical Corporate Finance. Elsevier/North-Holland.

Lichtenberg, F. R. (1992). Corporate Takeovers and Productivity. MIT Press, Cambridge, MA.

Lichtenberg, F. R. and D. Siegel (1990a). The effect of leveraged buyouts on productivity and related aspects of firm behavior. Journal of Financial Economics 27, 165-194.

Lichtenberg, F. R. and D. Siegel (1990b). The effect of ownership changes on the employment and wages of central office and other personnel. Journal of Law and Economics 33, 383-408.

Maksimovic, V. and G. Phillips (2001). The market for corporate assets: Who engages in mergers and asset sales and are there efficiency gains? Journal of Finance 56, 2019-2065.

Maksimovic, V. and G. Phillips (2002). Do conglomerate firms allocate resources inefficiently across industries? Theory and evidence. Journal of Finance 57, 721-767.

Maksimovic, V., G. Phillips, and N. R. Prabhala (2008). Post-merger restructuring and the boundaries of the firm. Working paper, University of Maryland.

Malmendier, U. and G. Tate (2008). Who makes acquisitions? CEO overconfidence and the market's reaction. Journal of Financial Economics 89, 20-43.

Martin, K. J. and J. McConnell (1991). Corporate performance, corporate takeovers, and management turnover. Journal of Finance 46, 671-687.

Masulis, R., C. Wang, and F. Xie (2007). Corporate governance and acquirer returns. Journal of Finance 62, 1851-1889.

McGuckin, R. and S. V. Nguyen (1995). On productivity and plant ownership change: New evidence from the longitudinal research database. RAND Journal of Economics 26, 257-276.

McGuckin, R. and S. V. Nguyen (2001). The impact of ownership changes: A view from labor markets. International Journal of Industrial Organization 19, 739-762. 
Mitchell, M. L. and J. H. Mulherin (1996). The impact of industry shocks on takeover and restructuring activity. Journal of Financial Economics 41, 193-229.

Moeller, S. B., F. P. Schlingemann, and R. M. Stulz (2004). Firm size and the gains from acquisitions. Journal of Financial Economics 73, 201-228.

Moeller, S. B., F. P. Schlingemann, and R. M. Stulz (2005). Wealth destruction on a massive scale? A study of acquiring-firm returns in the recent merger wave. Journal of Finance 60, 757-782.

Moeller, T. (2005). Let's make a deal! How shareholder control impacts merger payoffs. Journal of Financial Economics 76, 167-190.

Officer, M. S. (2003). Termination fees in mergers and acquisitions. Journal of Financial Economics 69, $431-467$.

Ouimet, P. and R. Zarutskie (2010). Mergers and employee wages. Working paper, University of North Carolina, Chapel Hill.

Pagano, M. and P. F. Volpin (2005). Managers, workers, and corporate control. Journal of Finance 60, $841-868$.

Pontiff, J., A. Shleifer, and M. Weisbach (1990). Reversions of excess pension assets after takeovers. RAND Journal of Economics 21, 600-613.

Rauh, J. D. (2006). Own company stock in defined contribution pension plans: A takeover defense? Journal of Financial Economics 81, 379-410.

Ravenscraft, D. J. and F. M. Scherer (1989). The profitability of mergers. International Journal of Industrial Organization 7, 101-116.

Rhodes-Kropf, M. and D. Robinson (2008). The market for mergers and the boundaries of the firm. Journal of Finance 62, 1169-1211.

Roll, R. (1986). The hubris hypothesis of corporate takeovers. Journal of Business 59, 197-216.

Rosett, J. G. (1990). Do union wealth concessions explain takeover premiums? Journal of Financial Economics 27, 263-282.

Savor, P. G. and Q. Lu (2009). Do stock mergers create value for acquirers. Journal of Finance 64, 1061-1097. 
Schoar, A. (2002). The effect of diversification on firm productivity. Journal of Finance 62, 2379-2403.

Seru, A. (2010). Firm boundaries matter: Evidence from conglomerates and r\&d activity. Journal of Financial Economics, forthcoming.

Servaes, H. (1991). Tobin's Q and the gains from takeovers. Journal of Finance 46, 409-419.

Servaes, H. (1994). Do takeover targets overinvest? Review of Financial Studies 7, 253-277.

Shleifer, A. and L. Summers (1988). Breach of trust in hostile takeovers. In A. J. Auerbach (Ed.), Corporate Takeovers: Causes and Consequences. University of Chicago Press, Chicago.

Shleifer, A. and R. Vishny (1988). Value maximization and the acquisition process. Journal of Economic Perspectives 2, 7-20.

Shleifer, A. and R. Vishny (1989). Management entrenchment: The case of manager-specific investments. Journal of Financial Economics 25, 123-139.

Wang, C. and F. Xie (2009). Corporate governance transfer and synergistic gains from mergers and acquisitions. Review of Financial Studies 62, 822-858.

Wulf, J. (2004). Do CEOs in mergers trade power for premium? Evidence from "mergers of equals". Journal of Law, Economics, and Organization 20, 60-101.

Yang, L. (2008). The real determinants of asset sales. Journal of Finance 62, 2231-2262. 


\section{Table 1: Number of Deals and Basic Deal Characteristics}

The table describes the basic characteristics of the takeover sample in this study. The sample consists of mergers from the SDC M\&As database in which the announcement date is between 1981 and 2002, the completion date is within 360 days of the announcement, and the target is a publicly-listed firm that can be matched to the ASM/CMF, maintained at U.S. Census Bureau. Column 2 reports the number of mergers completed each year. Column 3 and 4 report the mean and standard deviation of deal value (reported in SDC). Column 5 through 8 report the mean and standard deviation of the three-day Cumulative Abnormal Return (CAR) around deal announcements, for the target and the acquirer, respectively. CAR is estimated using a market model adjusted for CRSP value-weighted market index.

\begin{tabular}{ccrrrrrr}
\hline & & \multicolumn{3}{c}{ Deal Value } & \multicolumn{2}{c}{ Target CAR $_{(-1,+1)}$} & \multicolumn{2}{c}{ Acquirer CAR $_{(-1,+1)}$} \\
\hline Year & N & Mean & \multicolumn{1}{c}{ SD } & Mean & SD & Mean & SD \\
\hline 1981 & 15 & 322.8 & 457.9 & 0.251 & 0.332 & -0.004 & 0.052 \\
1982 & 19 & 219.4 & 285.8 & 0.162 & 0.148 & -0.013 & 0.047 \\
1983 & 34 & 157.1 & 239.3 & 0.110 & 0.149 & 0.016 & 0.122 \\
1984 & 48 & 285.3 & 415.3 & 0.138 & 0.171 & -0.009 & 0.059 \\
1985 & 60 & 747.6 & 1297.6 & 0.186 & 0.176 & -0.014 & 0.052 \\
1986 & 103 & 524.3 & 1163.8 & 0.167 & 0.177 & 0.004 & 0.051 \\
1987 & 76 & 468.6 & 733.9 & 0.216 & 0.187 & 0.019 & 0.058 \\
1988 & 124 & 504.3 & 1392.5 & 0.228 & 0.235 & -0.009 & 0.087 \\
1989 & 85 & 969.3 & 3662.5 & 0.213 & 0.209 & -0.007 & 0.070 \\
1990 & 53 & 506.4 & 917.9 & 0.272 & 0.269 & -0.020 & 0.047 \\
1991 & 24 & 1178.1 & 2385.8 & 0.345 & 0.385 & 0.018 & 0.087 \\
1992 & 16 & 195.4 & 262.1 & 0.292 & 0.202 & 0.035 & 0.081 \\
1993 & 40 & 312.0 & 666.6 & 0.287 & 0.213 & -0.007 & 0.056 \\
1994 & 42 & 984.9 & 2209.5 & 0.208 & 0.160 & -0.005 & 0.066 \\
1995 & 60 & 790.3 & 1646.6 & 0.224 & 0.177 & -0.012 & 0.058 \\
1996 & 83 & 1053.8 & 2754.4 & 0.226 & 0.237 & -0.001 & 0.069 \\
1997 & 85 & 746.4 & 1625.6 & 0.236 & 0.202 & 0.016 & 0.068 \\
1998 & 126 & 2226.3 & 7936.6 & 0.265 & 0.230 & 0.010 & 0.078 \\
1999 & 128 & 1444.3 & 3009.8 & 0.262 & 0.212 & 0.003 & 0.086 \\
2000 & 112 & 3095.4 & 10260.4 & 0.302 & 0.286 & -0.015 & 0.087 \\
2001 & 62 & 2239.3 & 5782.7 & 0.345 & 0.534 & -0.031 & 0.097 \\
2002 & 35 & 1919.5 & 5049.8 & 0.152 & 0.225 & -0.023 & 0.094 \\
\hline Total & 1430 & 949.6 & 4480.34 & 0.233 & 0.248 & -0.002 & 0.074 \\
\hline
\end{tabular}


Table 2: Descriptive Statistics for Target Firm/Plant Output and Employment

The table reports summary statistics for some variables at the target firm and plant level. The sample consists of mergers from the SDC M\&As database in which the announcement date is between 1981 and 2002, the completion date is within 360 days of the announcement, and the target is a publiclylisted firm that can be matched to the ASM/CMF, maintained at U.S. Census Bureau. T is the year when the merger is completed. Output is the total value of shipment, expressed in millions of dollars. Total factor productivity (TFP) is the residual from estimating a log linear Cobb-Douglas production function at the plant level, where one regresses the value of output on total payroll, capital stock, and material cost separately for each 3-digit SIC industry and year. Employment is the total number of employees.

\begin{tabular}{lccccccc}
\hline \multicolumn{1}{c}{ Panel A: Firm level } \\
\hline & \multicolumn{1}{c}{ Plants per firm } & \multicolumn{2}{c}{ Total employment } & \multicolumn{2}{c}{ Total output } \\
Timing & N & Mean & SD & Mean & SD & Mean & SD \\
\hline $\mathrm{T}-3$ & 1272 & 7.38 & 14.46 & 2729.4 & 6629.7 & 631.5 & 3223.8 \\
$\mathrm{~T}-2$ & 1305 & 7.54 & 15.25 & 2700.5 & 6530.7 & 645.1 & 3277.5 \\
$\mathrm{~T}-1$ & 1430 & 8.09 & 16.21 & 2531.7 & 6276.8 & 635.1 & 3367.6 \\
$\mathrm{~T}$ & 1275 & 7.51 & 15.25 & 2588.6 & 6365.9 & 664.6 & 3065.0 \\
$\mathrm{~T}+1$ & 1228 & 7.44 & 14.87 & 2540.7 & 6221.8 & 673.9 & 2928.2 \\
$\mathrm{~T}+2$ & 1169 & 7.22 & 14.42 & 2539.2 & 6347.1 & 711.2 & 3024.8 \\
$\mathrm{~T}+3$ & 1139 & 6.92 & 13.60 & 2427.7 & 5797.9 & 739.2 & 3139.6 \\
\hline
\end{tabular}

Panel B: Plant level

\begin{tabular}{lccccccc}
\hline & \multicolumn{2}{c}{ TFP } & \multicolumn{2}{c}{ Employment } & \multicolumn{2}{c}{ Output } \\
Timing & $\mathrm{N}$ & Mean & SD & Mean & SD & Mean & SD \\
\hline $\mathrm{T}-3$ & 9045 & 0.039 & 0.33 & 371.9 & 719.9 & 75.9 & 295.7 \\
$\mathrm{~T}-2$ & 9465 & 0.031 & 0.32 & 358.3 & 711.0 & 75.7 & 299.7 \\
$\mathrm{~T}-1$ & 11129 & 0.031 & 0.34 & 315.5 & 671.0 & 70.9 & 301.1 \\
$\mathrm{~T}$ & 9201 & 0.029 & 0.34 & 346.1 & 691.1 & 78.2 & 261.1 \\
$\mathrm{~T}+1$ & 8742 & 0.031 & 0.33 & 343.0 & 684.9 & 80.6 & 258.3 \\
$\mathrm{~T}+2$ & 8129 & 0.039 & 0.35 & 350.0 & 690.9 & 86.6 & 279.8 \\
$\mathrm{~T}+3$ & 7591 & 0.037 & 0.35 & 351.3 & 651.4 & 96.2 & 331.7 \\
\hline
\end{tabular}




\section{Table 3: The Effect of Takeovers on Efficiency}

The table reports estimates of a plant-level differences-in-differences regression of $Y_{i t}=\alpha+\beta_{1}$ After $_{t}+$ $\beta_{2}\left(\right.$ After $_{t} *$ Target $\left._{i}\right)+$ Plant \& Year FE $+\epsilon_{i t}$. The sample consists of mergers from the SDC M\&As database in which the announcement date is between 1981 and 2002, the completion date is within 360 days of the announcement, and the target is a publicly-listed firm that can be matched to the ASM/CMF, maintained at U.S. Census Bureau. Total factor productivity (TFP) is the residual from estimating a log linear Cobb-Douglas production function at the plant level, where one regresses the value of output on total payroll, capital stock, and material cost separately for each 3-digit SIC and year. Profit margin is the ratio of profit (sales minus material cost and labor cost) to sales. Return to capital is the ratio of profit to capital stock. The data are an unbalanced six-period panel $(\mathrm{T}-3$, $\mathrm{T}-2, \mathrm{~T}-1, \mathrm{~T}+1, \mathrm{~T}+2$, and $\mathrm{T}+3$ ) for target plants and control plants. $\mathrm{T}$, the year when the merger is completed, is dropped out from the analysis. After is a dummy variable that equals one for $\mathrm{T}+1$, $\mathrm{T}+2$ and $\mathrm{T}+3$, and zero for $\mathrm{T}-1, \mathrm{~T}-2$ and $\mathrm{T}-3$. Target is a dummy variable that equals one if a plant's parent firm is acquired at year $\mathrm{T}$, and zero if a plant is a control plant. The control sample is constructed by selecting plants that are comparable to target plants in terms of industry, size, and TFP prior to the takeover. Heteroskedastic-robust standard errors clustered at the firm level are in parentheses. The symbols ${ }^{* * *},{ }^{* *}$, and ${ }^{*}$ indicate statistical significance at the 1,5 , and 10 percent levels, respectively.

\begin{tabular}{lcccccc}
\hline & \multicolumn{2}{c}{ TFP } & \multicolumn{2}{c}{ Profit Margin } & \multicolumn{2}{c}{ Return to Capital } \\
& $(1)$ & $(2)$ & $(3)$ & $(4)$ & $(5)$ & $(6)$ \\
\hline After & $-0.013^{* * *}$ & $-0.013^{* * *}$ & $-0.006^{* * *}$ & $-0.007^{* * *}$ & $-0.111^{* * *}$ & $-0.110^{* * *}$ \\
& $(0.003)$ & $(0.003)$ & $(0.001)$ & $(0.001)$ & $(0.032)$ & $(0.032)$ \\
After*Target & $0.012^{* * *}$ & $0.011^{* * *}$ & 0.004 & $0.004^{* *}$ & $0.253^{* * *}$ & $0.254^{* * *}$ \\
& $(0.004)$ & $(0.004)$ & $(0.003)$ & $(0.002)$ & $(0.048)$ & $(0.048)$ \\
Log(employment) & & $-0.014^{* * *}$ & & $-0.015^{* * *}$ & & 0.043 \\
& & $(0.003)$ & & $(0.002)$ & & $(0.039)$ \\
Constant & $0.051^{* * *}$ & $0.126^{* * *}$ & $0.284^{* * *}$ & $0.365^{* * *}$ & $1.330^{* * *}$ & $1.106^{* * *}$ \\
& $(0.014)$ & $(0.020)$ & $(0.008)$ & $(0.012)$ & $(0.083)$ & $(0.222)$ \\
Plant FE & Yes & Yes & Yes & Yes & Yes & Yes \\
Year FE & Yes & Yes & Yes & Yes & Yes & Yes \\
Observations & 173,648 & 173,648 & 173,648 & 173,648 & 173,648 & 173,648 \\
$\mathrm{R}^{2}$ & 0.53 & 0.53 & 0.58 & 0.58 & 0.39 & 0.40 \\
\hline
\end{tabular}


Table 4: The Effect of Takeovers on Outputs and Inputs

The table reports estimates of a plant-level differences-in-differences regression of $\log \left(Y_{i t}\right)=\alpha+$ $\beta_{1}$ After $_{t}+\beta_{2}\left(\right.$ After $_{t} *$ Target $\left._{i}\right)+$ Plant \& Year FE $+\epsilon_{i t}$. The sample consists of mergers from the SDC M\&As database in which the announcement date is between 1981 and 2002, the completion date is within 360 days of the announcement, and the target is a publicly-listed firm that can be matched to the ASM/CMF, maintained at U.S. Census Bureau. Output is the total value of shipment. Investment is the total capital expenditure. Material is the sum of cost of materials, parts, energy, and electricity costs. Wage is calculated as total salaries divided by total number of employees. Employment is the total number of employees. All these variables are in logs. The data are an unbalanced six-year panel $(\mathrm{T}-3, \mathrm{~T}-2, \mathrm{~T}-1, \mathrm{~T}+1, \mathrm{~T}+2$, and $\mathrm{T}+3)$ for target and control plants. $\mathrm{T}$, the year when the merger is completed, is dropped out from the analysis. After is a dummy variable that equals one for year $\mathrm{T}+1, \mathrm{~T}+2$, and $\mathrm{T}+3$, and zero for $\mathrm{T}-1, \mathrm{~T}-2$, and $\mathrm{T}-3$. Target is a dummy variable that equals one if a plant's parent firm is acquired at year $\mathrm{T}$ and zero if a plant is a control plant. The control sample is constructed by selecting plants that are comparable to target plants in terms of industry, size, and TFP prior to the takeover. Heteroskedastic-robust standard errors clustered at firm level are in parentheses. The symbols ${ }^{* * *},{ }^{* *}$, and ${ }^{*}$ indicate statistical significance at the 1,5 , and 10 percent levels, respectively.

\begin{tabular}{|c|c|c|c|c|c|}
\hline & $\begin{array}{l}\text { Output } \\
\text { (1) }\end{array}$ & $\begin{array}{c}\text { Investment } \\
(2)\end{array}$ & $\begin{array}{c}\text { Materials } \\
\quad(3)\end{array}$ & $\begin{array}{l}\text { Wage } \\
(4)\end{array}$ & $\begin{array}{c}\text { Employment } \\
(5)\end{array}$ \\
\hline After & $\begin{array}{c}-0.023^{* * *} \\
(0.004)\end{array}$ & $\begin{array}{c}-0.101^{* * *} \\
(0.014)\end{array}$ & $\begin{array}{c}-0.017^{* * *} \\
(0.005)\end{array}$ & $\begin{array}{c}0.003 \\
(0.002)\end{array}$ & $\begin{array}{c}-0.013^{* * *} \\
(0.004)\end{array}$ \\
\hline After*Target & $\begin{array}{c}-0.002 \\
(0.006)\end{array}$ & $\begin{array}{c}-0.128^{* * *} \\
(0.029)\end{array}$ & $\begin{array}{r}-0.009^{*} \\
(0.005)\end{array}$ & $\begin{array}{r}-0.005^{*} \\
(0.003)\end{array}$ & $\begin{array}{c}-0.023^{* * *} \\
(0.007)\end{array}$ \\
\hline Log(employment) & $\begin{array}{l}0.802^{* * *} \\
(0.008)\end{array}$ & $\begin{array}{l}1.105^{* * *} \\
(0.019)\end{array}$ & $\begin{array}{l}0.802^{* * *} \\
(0.009)\end{array}$ & $\begin{array}{c}-0.089^{* * *} \\
(0.004)\end{array}$ & \\
\hline Constant & $\begin{array}{l}5.366^{* * *} \\
(0.044)\end{array}$ & $\begin{array}{l}0.066^{* * *} \\
(0.130)\end{array}$ & $\begin{array}{l}4.614^{* * *} \\
(0.052)\end{array}$ & $\begin{array}{l}11.052^{* * *} \\
(0.021)\end{array}$ & $\begin{array}{l}5.238^{* * *} \\
(0.025)\end{array}$ \\
\hline Plant FE & Yes & Yes & Yes & Yes & Yes \\
\hline Year FE & Yes & Yes & Yes & Yes & Yes \\
\hline Observations & 173,648 & 173,648 & 173,648 & 173,648 & 173,648 \\
\hline \multirow[t]{3}{*}{$\mathrm{R}^{2}$} & 0.96 & 0.70 & 0.94 & 0.83 & 0.94 \\
\hline & & \multicolumn{2}{|c|}{ Production Worker } & \multicolumn{2}{|c|}{ Non-production Worker } \\
\hline & & $\begin{array}{l}\text { Wage } \\
(1)\end{array}$ & $\begin{array}{c}\text { Employment } \\
(2)\end{array}$ & $\begin{array}{c}\text { Wage } \\
(3)\end{array}$ & $\begin{array}{c}\text { Employment } \\
(4)\end{array}$ \\
\hline After & & $\begin{array}{l}0.006^{* * *} \\
(0.002)\end{array}$ & $\begin{array}{c}-0.018^{* * *} \\
(0.004)\end{array}$ & $\begin{array}{r}-0.024^{*} \\
(0.013)\end{array}$ & $\begin{array}{c}-0.001 \\
(0.006)\end{array}$ \\
\hline After*Target & & $\begin{array}{c}-0.002 \\
(0.004)\end{array}$ & $\begin{array}{r}-0.012^{*} \\
(0.007)\end{array}$ & $\begin{array}{c}-0.001 \\
(0.026)\end{array}$ & $\begin{array}{c}-0.048^{* * *} \\
(0.011)\end{array}$ \\
\hline Log(employment) & & $\begin{array}{c}-0.075^{* * *} \\
(0.004)\end{array}$ & & $\begin{array}{l}0.415^{* * *} \\
(0.028)\end{array}$ & \\
\hline Constant & & $\begin{array}{l}10.839^{* * *} \\
(0.023)\end{array}$ & $\begin{array}{l}4.936^{* * *} \\
(0.027)\end{array}$ & $\begin{array}{l}8.508^{* * *} \\
(0.158)\end{array}$ & $\begin{array}{l}3.677^{* * *} \\
(0.034)\end{array}$ \\
\hline Plant FE & & Yes & Yes & Yes & Yes \\
\hline Year FE & & Yes & Yes & Yes & Yes \\
\hline Observations & & 173,648 & 173,648 & 173,648 & 173,648 \\
\hline $\mathrm{R}^{2}$ & & $0.78 \quad 40$ & 0.93 & 0.55 & 0.88 \\
\hline
\end{tabular}




\section{Table 5: The Effect of Takeovers on Plant Closure}

The table reports estimates of a plant-level regression of Exit $i t=\alpha+\beta_{1} \operatorname{Target}_{i}+\beta_{2} \mathrm{TFP}_{i}+\beta_{3}\left(\mathrm{TFP}_{i} *\right.$ Target $\left._{i}\right)+\epsilon_{i t}$, where $\mathrm{t}=\mathrm{T}, \mathrm{T}+1, \mathrm{~T}+2, \mathrm{~T}+3$, and cumulatively from $\mathrm{T}$ to $\mathrm{T}+3$. The sample consists of mergers from the SDC M\&As database in which the announcement date is between 1981 and 2002, the completion date is within 360 days of the announcement, and the target is a publicly-listed firm that can be matched to the ASM/CMF, maintained at U.S. Census Bureau. The dependent variable Exit is a dummy variable that equals one if a plant is closed at time $t$ and zero otherwise. Target is a dummy variable that equals one if the plant's parent firm is acquired at year $\mathrm{T}$ and zero if a plant is a control plant. The control sample is constructed by selecting plants that are comparable to target plants in terms of industry, size, and TFP prior to the takeover. Total factor productivity (TFP) is the residual from estimating a log linear Cobb-Douglas production function at plant level, where one regresses the value of output on total payroll, capital stock, and material cost separately for each 3-digit SIC and year. The regression also controls for industry and year fixed effects as well as the number of employees (in logs). Columns 1 through 5 report OLS regression results and column 6 reports marginal effect from a probit estimation. Heteroskedastic-robust standard errors are in parentheses. The symbols $* * *$, $* *$, and $*$ indicate statistical significance at the 1,5 , and 10 percent levels, respectively.

\begin{tabular}{|c|c|c|c|c|c|c|}
\hline & \multicolumn{6}{|c|}{ Dependent Variable: Exit $=1 / 0$ at period $\mathrm{t}$} \\
\hline & \multirow{3}{*}{$\begin{array}{c}\mathrm{T} \\
\mathrm{OLS} \\
(1)\end{array}$} & \multirow{3}{*}{$\begin{array}{c}\mathrm{T}+1 \\
\text { OLS } \\
(2)\end{array}$} & \multirow{3}{*}{$\begin{array}{c}\mathrm{T}+2 \\
\text { OLS } \\
(3)\end{array}$} & \multirow{3}{*}{$\begin{array}{c}\mathrm{T}+3 \\
\text { OLS } \\
(4)\end{array}$} & \multicolumn{2}{|c|}{$\mathrm{T}-\mathrm{T}+3$} \\
\hline & & & & & OLS & Probit \\
\hline & & & & & $(5)$ & $(6)$ \\
\hline \multirow[t]{2}{*}{ Target } & $0.005^{* * *}$ & $0.022^{* * *}$ & $0.022^{* * *}$ & $0.014^{* * *}$ & $0.064^{* * *}$ & $0.069^{* * *}$ \\
\hline & $(0.002)$ & $(0.002)$ & $(0.002)$ & $(0.002)$ & $(0.004)$ & $(0.005)$ \\
\hline \multirow[t]{2}{*}{ Log(employment) } & $-0.013^{* * *}$ & $-0.013^{* * *}$ & $-0.010^{* * *}$ & $-0.008^{* * *}$ & $-0.046^{* * *}$ & -0.046 \\
\hline & $(0.001)$ & $(0.001)$ & $(0.001)$ & $(0.001)$ & $(0.001)$ & $(0.001)$ \\
\hline \multirow[t]{2}{*}{ TFP } & $-0.006^{* * *}$ & $-0.009^{* * *}$ & -0.004 & $-0.011^{* * *}$ & $-0.028^{* * *}$ & $-0.033^{* * *}$ \\
\hline & $(0.002)$ & $(0.003)$ & $(0.003)$ & $(0.003)$ & $(0.006)$ & $(0.006)$ \\
\hline \multirow[t]{2}{*}{ Target*TFP } & $-0.009^{*}$ & $-0.013^{* *}$ & $-0.016^{* * *}$ & 0.009 & $-0.03^{* * *}$ & $-0.021^{* *}$ \\
\hline & $(0.005)$ & $(0.006)$ & $(0.006)$ & $(0.006)$ & $(0.011)$ & $(0.010)$ \\
\hline Industry FE & Yes & Yes & Yes & Yes & Yes & Yes \\
\hline Year FE & Yes & Yes & Yes & Yes & Yes & Yes \\
\hline Observations & 49,679 & 49,679 & 49,679 & 49,679 & 49,679 & 49,679 \\
\hline $\mathrm{R}^{2}$ & 0.02 & 0.02 & 0.02 & 0.30 & 0.19 & 0.22 \\
\hline
\end{tabular}




\section{Table 6: The Effect of Takeovers on Efficiency with a Different Control Sample}

The table reports estimates of a plant-level differences-in-differences regression of $Y_{i t}=\alpha+\beta_{1}$ After $_{t}+$ $\beta_{2}\left(\right.$ After $_{t} *$ Target $\left._{i}\right)+$ Plant \& Year FE $+\epsilon_{i t}$. The sample consists of mergers from the SDC M\&As database in which the announcement date is between 1981 and 2002, the completion date is within 360 days of the announcement, and the target firm is a publicly-listed firm that can be matched to the ASM/CMF, maintained at U.S. Census Bureau. Total factor productivity (TFP) is the residual from estimating a log linear Cobb-Douglas production function at the plant level, where one regresses the value of output on total payroll, capital stock, and material cost separately for each 3-digit SIC and year. Profit margin is the ratio of profit (sales minus material cost and labor cost) to sales. Return to capital is the ratio of profit to capital stock. The data are an unbalanced six-period panel ( $\mathrm{T}-3$, $\mathrm{T}-2, \mathrm{~T}-1, \mathrm{~T}+1, \mathrm{~T}+2$, and $\mathrm{T}+3)$ for target plants and control plants. $\mathrm{T}$, the year when the merger is completed, is dropped out from the analysis. After is a dummy variable that equals one for $\mathrm{T}+1$, $\mathrm{T}+2$ and $\mathrm{T}+3$, and zero for $\mathrm{T}-1, \mathrm{~T}-2$ and $\mathrm{T}-3$. Target is a dummy variable that equals one if a plant's parent firm is acquired at year $\mathrm{T}$, and zero if a plant is a control plant. The control sample is constructed by selecting plants that are comparable to targeted plants in terms of industry, age, and employment prior to the takeover. Heteroskedastic-robust standard errors clustered at the firm level are in parentheses. The symbols ${ }^{* * *},{ }^{* *}$, and $*^{*}$ indicate statistical significance at the 1,5 , and 10 percent levels, respectively.

\begin{tabular}{lcccccc}
\hline & \multicolumn{2}{c}{ TFP } & \multicolumn{2}{c}{ Profit Margin } & \multicolumn{2}{c}{ Return to Capital } \\
& $(1)$ & $(2)$ & $(3)$ & $(4)$ & $(5)$ & $(6)$ \\
\hline After & $-0.006^{* *}$ & $-0.006^{* *}$ & -0.002 & -0.002 & $-0.056^{*}$ & $-0.054^{*}$ \\
& $(0.002)$ & $(0.003)$ & $(0.001)$ & $(0.001)$ & $(0.031)$ & $(0.031)$ \\
After*Target & $0.009^{*}$ & $0.009^{* *}$ & 0.001 & 0.001 & $0.169^{* * *}$ & $0.170^{* * *}$ \\
& $(0.005)$ & $(0.004)$ & $(0.003)$ & $(0.003)$ & $(0.048)$ & $(0.048)$ \\
Log(employment) & & $-0.021^{* * *}$ & & $-0.020^{* * *}$ & & $0.067^{*}$ \\
& & $(0.005)$ & & $(0.002)$ & & $(0.037)$ \\
Constant & $0.037^{* * *}$ & $0.146^{* * *}$ & $0.278^{* * *}$ & $0.380^{* * *}$ & $1.274^{* * *}$ & $0.923^{* * *}$ \\
& $(0.010)$ & $(0.028)$ & $(0.006)$ & $(0.012)$ & $(0.081)$ & $(0.210)$ \\
Plant FE & Yes & Yes & Yes & Yes & Yes & Yes \\
Year FE & Yes & Yes & Yes & Yes & Yes & Yes \\
Observations & 177,953 & 177,953 & 177,953 & 177,953 & 177,953 & 177,953 \\
$\mathrm{R}^{2}$ & 0.53 & 0.53 & 0.57 & 0.57 & 0.40 & 0.40 \\
\hline
\end{tabular}


Table 7: The Effect of Takeovers on Outputs and Inputs with a Different Control Sample

The table reports estimates of a plant-level differences-in-differences regression of $\log \left(Y_{i t}\right)=\alpha+$ $\beta_{1}$ After $_{t}+\beta_{2}\left(\right.$ After $_{t} *$ Target $\left._{i}\right)+$ Plant \& Year FE $+\epsilon_{i t}$. The sample consists of mergers from the SDC M\&As database in which the announcement date is between 1981 and 2002, the completion date is within 360 days of the announcement, and the target is a publicly-listed firm that can be matched to the ASM/CMF, maintained at U.S. Census Bureau. Output is the total value of shipment. Investment is total capital expenditure. Material is the sum of cost of materials, parts, energy, and electricity costs. Wage is the total salaries divided by total number of employees, expressed in 2005 dollars. Employment is the total number of employees. All these variables are in logs. The data are an unbalanced six-year panel $(\mathrm{T}-3, \mathrm{~T}-2, \mathrm{~T}-1, \mathrm{~T}+1, \mathrm{~T}+2$, and $\mathrm{T}+3)$ for target plants and control plants. $\mathrm{T}$, the year when the merger is completed, is dropped out from the analysis. After is a dummy variable that equals one for $\mathrm{T}+1, \mathrm{~T}+2$ and $\mathrm{T}+3$, and zero for $\mathrm{T}-1, \mathrm{~T}-2$ and $\mathrm{T}-3$. Target is a dummy variable that equals one if a plant's parent firm is acquired at $\mathrm{T}$ and zero if a plant is a control plant. The control sample is constructed by selecting plants that are comparable to target plants in terms of industry, age, and size prior to the takeover. Heteroskedastic-robust standard errors clustered at firm level are in parentheses. The symbols ${ }^{* * *},{ }^{* *}$, and ${ }^{*}$ indicate statistical significance at the 1,5 , and 10 percent levels, respectively.

\begin{tabular}{|c|c|c|c|c|c|}
\hline & $\begin{array}{l}\text { Output } \\
\text { (1) }\end{array}$ & $\begin{array}{c}\text { Investment } \\
(2)\end{array}$ & $\begin{array}{c}\text { Materials } \\
\quad(3)\end{array}$ & $\begin{array}{l}\text { Wage } \\
(4)\end{array}$ & $\begin{array}{c}\text { Employment } \\
(5)\end{array}$ \\
\hline After & $\begin{array}{c}-0.015^{* * *} \\
(0.003)\end{array}$ & $\begin{array}{c}-0.109^{* * *} \\
(0.013)\end{array}$ & $\begin{array}{c}-0.013^{* * *} \\
(0.005)\end{array}$ & $\begin{array}{c}0.001 \\
(0.002)\end{array}$ & $\begin{array}{c}-0.021^{* * *} \\
(0.004)\end{array}$ \\
\hline After*Target & $\begin{array}{c}-0.004 \\
(0.007)\end{array}$ & $\begin{array}{c}-0.110^{* * *} \\
(0.030)\end{array}$ & $\begin{array}{c}-0.010 \\
(0.009)\end{array}$ & $\begin{array}{c}-0.007^{* * *} \\
(0.003)\end{array}$ & $\begin{array}{c}-0.016^{* *} \\
(0.007)\end{array}$ \\
\hline Log(employment) & $\begin{array}{l}0.801^{* * *} \\
(0.008)\end{array}$ & $\begin{array}{l}1.095^{* * *} \\
(0.018)\end{array}$ & $\begin{array}{l}0.804^{* * *} \\
(0.009)\end{array}$ & $\begin{array}{c}-0.085^{* * *} \\
(0.004)\end{array}$ & \\
\hline Constant & $\begin{array}{l}5.357^{* * *} \\
(0.047)\end{array}$ & $\begin{array}{c}0.087 \\
(0.120)\end{array}$ & $\begin{array}{l}4.581^{* * *} \\
(0.050)\end{array}$ & $\begin{array}{l}11.012^{* * *} \\
(0.020)\end{array}$ & $\begin{array}{l}5.255^{* * *} \\
(0.023)\end{array}$ \\
\hline Plant FE & Yes & Yes & Yes & Yes & Yes \\
\hline Year FE & Yes & Yes & Yes & Yes & Yes \\
\hline Observations & 177,953 & 177,953 & 177,953 & 177,953 & 177,953 \\
\hline \multirow[t]{3}{*}{$\mathrm{R}^{2}$} & 0.96 & 0.70 & 0.94 & 0.83 & 0.94 \\
\hline & & \multicolumn{2}{|c|}{ Production Worker } & \multicolumn{2}{|c|}{ Non-production Worker } \\
\hline & & $\begin{array}{l}\text { Wage } \\
(1)\end{array}$ & $\begin{array}{c}\text { Employment } \\
(2)\end{array}$ & $\begin{array}{c}\text { Wage } \\
(3)\end{array}$ & $\begin{array}{c}\text { Employment } \\
(4)\end{array}$ \\
\hline After & & $\begin{array}{l}0.006^{* * *} \\
(0.002)\end{array}$ & $\begin{array}{c}-0.025^{* * *} \\
(0.004)\end{array}$ & $\begin{array}{r}-0.021^{*} \\
(0.013)\end{array}$ & $\begin{array}{c}-0.007 \\
(0.006)\end{array}$ \\
\hline After*Target & & $\begin{array}{c}-0.004 \\
(0.004)\end{array}$ & $\begin{array}{c}-0.006 \\
(0.007)\end{array}$ & $\begin{array}{c}-0.017 \\
(0.027)\end{array}$ & $\begin{array}{c}-0.046^{* * *} \\
(0.012)\end{array}$ \\
\hline Log(employment) & & $\begin{array}{c}-0.073^{* * *} \\
(0.004)\end{array}$ & & $\begin{array}{l}0.377^{* * *} \\
(0.027)\end{array}$ & \\
\hline Constant & & $\begin{array}{l}10.808 \\
(0.023)\end{array}$ & $\begin{array}{c}4.966 \\
(0.023)\end{array}$ & $\begin{array}{c}8.634 \\
(0.152)\end{array}$ & $\begin{array}{c}3.639 \\
(0.030)\end{array}$ \\
\hline Plant FE & & Yes & Yes & Yes & Yes \\
\hline Year FE & & Yes & Yes & Yes & Yes \\
\hline Observations & & 177,953 & 177,953 & 177,953 & 177,953 \\
\hline $\mathrm{R}^{2}$ & & $0.78 \quad 43$ & 0.93 & 0.55 & 0.88 \\
\hline
\end{tabular}


Table 8: Summary Statistics of Key Variables in Announcement Returns Analysis

The table reports mean, standard deviation, and pairwise correlation for several variables. The sample consists of mergers from the SDC M\&As database in which the announcement date is between 1981 and 2002, the completion date is within 360 days of the announcement, and the target is a publiclylisted firm that can be matched to the ASM/CMF, maintained at U.S. Census Bureau. Offer Premium is the ratio of the transaction value to target's equity value 30 days before announcement. Acquirer CAR is the three-day cumulative abnormal returns (CAR), estimated using a market model, for the acquiring firm. Combined CAR is equity-value weighted average of target's CAR and acquirer's CAR. TFP is constructed as an employment-weighted sum of all of the plants' TFP for the target firm. $\Delta \mathrm{TFP}=\mathrm{TFP}_{\mathrm{T}+1}-\mathrm{TFP}_{\mathrm{T}-1} ; \Delta$ Payroll $=\log \left(\mathrm{Payroll}_{\mathrm{T}+1}\right)-\log \left(\right.$ Payroll $\left._{\mathrm{T}-1}\right)$.

\begin{tabular}{|c|c|c|c|c|c|c|c|c|c|}
\hline & & $\mathrm{N}$ & Mean & $\mathrm{SD}$ & (1) & $(2)$ & $(3)$ & (4) & $(5)$ \\
\hline (1) & $\Delta \mathrm{TFP}$ & 1226 & 0.011 & 0.259 & 1 & & & & \\
\hline (2) & $\Delta$ Payroll & 1226 & -0.048 & 0.444 & -0.17 & 1 & & & \\
\hline (3) & Offer Premium & 1226 & 0.782 & 1.613 & 0.03 & 0.005 & 1 & & \\
\hline (4) & Acquirer CAR & 660 & -0.002 & 0.074 & 0.005 & 0.001 & -0.03 & 1 & \\
\hline (5) & Combined CAR & 660 & 0.051 & 0.094 & 0.047 & -0.006 & 0.001 & 0.58 & 1 \\
\hline
\end{tabular}




\section{Table 9: Determinants of Combined CAR}

The table reports estimates of a firm-level OLS regression explaining the combined CAR. The sample consists of mergers from the SDC M\&As database in which the announcement date is between 1981 and 2002, the completion date is within 360 days of the announcement, and the target is a publiclylisted firm that can be matched to the ASM/CMF, maintained at U.S. Census Bureau. CAR $_{(-1,+1)}$ is equity value weighted average of target's CAR and acquirer's CAR, which are estimated using a market model adjusting for CRSP value-weighted market index. TFP is constructed as an employmentweighted sum of all of the plants' TFP for the target firm. $\Delta \mathrm{TFP}=\mathrm{TFP}_{\mathrm{T}+1}-\mathrm{TFP}_{\mathrm{T}-1} ; \Delta$ Payroll $=$ $\log \left(\right.$ Payroll $\left._{\mathrm{T}+1}\right)-\log \left(\right.$ Payroll $\left._{\mathrm{T}-1}\right)$. RelaSize is the ratio of the target's market value to the sum of target's and acquirer's market value. All Cash is a dummy variable that equals one if the entire transaction value was paid by cash and zero otherwise. Some Stock is a dummy variable that equals one if at least some portion of the transaction was paid by stock and zero otherwise. Private Acquirer is a dummy variable that equals one if the acquirer is not a publicly-listed firm and zero otherwise. Premium is the ratio of transaction value to the target's market value of 30 trading days before announcement. Related is a dummy variable that equals one if target and acquirer share the same primary 2-digit SIC industry. Log(Assets) is the logarithm of the target firm's book assets. Marketto-book is the ratio of market value of assets to the book value of assets. All specifications control for target/acquirer industry (2-digit SIC) and year fixed effects. Heteroskedastic-robust standard errors are in parentheses. The symbols ${ }^{* * *},{ }^{* *}$, and ${ }^{*}$ indicate statistical significance at the 1,5 , and 10 percent levels, respectively.

\begin{tabular}{|c|c|c|c|c|c|c|c|c|}
\hline & $(1)$ & $(2)$ & $\begin{array}{c}\text { Dependent } \\
\text { (3) }\end{array}$ & $\begin{array}{l}\text { Variable: } \\
\text { (4) }\end{array}$ & $\begin{array}{c}\text { Combined } \\
(5)\end{array}$ & $\begin{array}{c}\mathrm{CAR}_{(-1,+1)} \\
(6)\end{array}$ & $(7)$ & $(8)$ \\
\hline \multirow[t]{2}{*}{$\Delta \mathrm{TFP}$} & $0.026^{*}$ & $0.039^{* *}$ & & & $0.027^{*}$ & $0.040^{* *}$ & -0.005 & -0.018 \\
\hline & $(0.015)$ & $(0.016)$ & & & $(0.015)$ & $(0.017)$ & $(0.018)$ & $(0.018)$ \\
\hline \multirow[t]{2}{*}{$\Delta$ Payroll } & & & 0.001 & -0.002 & 0.003 & 0.001 & 0.002 & 0.006 \\
\hline & & & $(0.008)$ & $(0.010)$ & $(0.008)$ & $(0.010)$ & $(0.010)$ & $(0.011)$ \\
\hline \multirow[t]{2}{*}{ RelaSize } & & & & & & & $0.177^{* * *}$ & $0.183^{* * *}$ \\
\hline & & & & & & & $(0.014)$ & $(0.018)$ \\
\hline \multirow[t]{2}{*}{ RelaSize* $\Delta \mathrm{TFP}$} & & & & & & & $0.118^{* * *}$ & $0.279^{* * *}$ \\
\hline & & & & & & & $(0.053)$ & $(0.066)$ \\
\hline \multirow{2}{*}{ RelaSize* $\Delta$ Payroll } & & & & & & & -0.021 & -0.048 \\
\hline & & & & & & & $(0.036)$ & $(0.042)$ \\
\hline \multirow[t]{2}{*}{ Related } & $0.021^{* *}$ & $0.025^{* *}$ & $0.022^{* *}$ & $0.027^{* *}$ & $0.022^{* *}$ & $0.025^{* *}$ & $0.016^{* *}$ & $0.013^{*}$ \\
\hline & $(0.008)$ & $(0.009)$ & $(0.008)$ & $(0.009)$ & $(0.007)$ & $(0.008)$ & $(0.007)$ & $(0.008)$ \\
\hline \multirow[t]{2}{*}{ Premium } & 0.001 & $0.007^{* *}$ & 0.001 & $0.008^{* *}$ & 0.001 & $0.007^{* *}$ & $0.003^{*}$ & $0.012^{* * *}$ \\
\hline & $(0.002)$ & $(0.003)$ & $(0.002)$ & $(0.003)$ & $(0.002)$ & $(0.003)$ & $(0.002)$ & $(0.003)$ \\
\hline \multirow[t]{2}{*}{ All cash } & 0.001 & 0.002 & 0.001 & 0.004 & 0.001 & 0.002 & 0.005 & 0.010 \\
\hline & $(0.010)$ & $(0.011)$ & $(0.010)$ & $(0.011)$ & $(0.010)$ & $(0.011)$ & $(0.009)$ & $(0.010)$ \\
\hline \multirow[t]{2}{*}{ Some stock } & $-0.036^{* * *}$ & $-0.028^{* *}$ & $-0.034^{* * *}$ & $-0.027^{* *}$ & $-0.036^{* * *}$ & $-0.028^{* *}$ & $-0.029^{* * *}$ & -0.017 \\
\hline & $(0.009)$ & $(0.011)$ & $(0.009)$ & $(0.012)$ & $(0.010)$ & $(0.012)$ & $(0.008)$ & $(0.010)$ \\
\hline \multirow[t]{2}{*}{$\log$ (Asset) } & & $-0.007^{* * *}$ & & $-0.007^{* * *}$ & & $-0.007^{* * *}$ & & -0.002 \\
\hline & & $(0.002)$ & & $(0.002)$ & & $(0.002)$ & & $(0.002)$ \\
\hline \multirow[t]{2}{*}{ Market-to-book } & & $-0.009^{* * *}$ & & $-0.009^{* * *}$ & & $-0.009^{* * *}$ & & -0.004 \\
\hline & & $(0.003)$ & & $(0.003)$ & & $(0.003)$ & & $(0.003)$ \\
\hline \multirow[t]{2}{*}{ Constant } & $0.058^{* * *}$ & $0.107^{* * *}$ & $0.056^{* * *}$ & $0.106^{* * *}$ & $0.058^{* * *}$ & $0.107^{* * *}$ & 0.007 & 0.009 \\
\hline & $(0.008)$ & $(0.021)$ & $(0.008)$ & $(0.021)$ & $(0.008)$ & $(0.021)$ & $(0.008)$ & $(0.021)$ \\
\hline Observations & 660 & 459 & 6645 & 459 & 660 & 459 & 660 & 459 \\
\hline $\mathrm{R}^{2}$ & 0.04 & 0.11 & 0.04 & 0.09 & 0.04 & 0.11 & 0.24 & 0.32 \\
\hline
\end{tabular}


Table 10: Determinants of Offer Premium

The table reports estimates of firm-level OLS regression explaining the target's offer premium. The sample consists of mergers from the SDC M\&As database in which the announcement date is between 1981 and 2002, the completion date is within 360 days of the announcement, and the target is a publicly-listed firm that can be matched to the ASM/CMF, maintained at U.S. Census Bureau. Offer premium is the ratio of transaction value to target's market value 30 trading days before announcement. TFP is constructed as an employment-weighted sum of all of the plants' TFP for the target firm. $\Delta \mathrm{TFP}=\mathrm{TFP}_{\mathrm{T}+1}-\mathrm{TFP}_{\mathrm{T}-1} ; \Delta$ Payroll $=\log \left(\right.$ Payroll $\left._{\mathrm{T}+1}\right)-\log \left(\right.$ Payroll $\left._{\mathrm{T}-1}\right)$. All Cash is a dummy variable that equals one if the entire transaction value was paid by cash and zero otherwise. Some Stock is a dummy variable that equals one if at least some portion of the transaction was paid by stock and zero otherwise. Private Acquirer is a dummy variable that equals one if the acquirer is not a publicly-listed firm and zero otherwise. Related is a dummy variable that equals one if target and acquirer share the same primary 2-digit SIC industry. 52-W High Price is the ratio of target's highest price in the previous 52 weeks to target's price 30 days before announcement. $\log ($ Assets) is the logarithm of the target's book assets. Market-to-book is the ratio of market value to the book value of assets for the target. All specifications control for target/acquirer industry (2-digit SIC) and year fixed effects. Heteroskedastic-robust standard errors are in parentheses. The symbols ***, **, and $*$ indicate statistical significance at the 1,5 , and 10 percent levels, respectively.

\begin{tabular}{|c|c|c|c|c|c|c|c|c|}
\hline & (1) & $(2)$ & $\begin{array}{l}\text { Depend } \\
\text { (3) }\end{array}$ & $\begin{array}{l}\text { dent Variab } \\
\text { (4) }\end{array}$ & $\begin{array}{l}\text { le: Offer P } \\
(5)\end{array}$ & $\begin{array}{r}\text { remium } \\
(6)\end{array}$ & $(7)$ & $(8)$ \\
\hline \multirow[t]{2}{*}{$\Delta \mathrm{TFP}$} & $0.247^{* *}$ & $0.268^{* *}$ & & & $0.319^{* *}$ & & $0.345^{* *}$ & $0.379^{* *}$ \\
\hline & $(0.109)$ & $(0.121)$ & & & $(0.122)$ & & $(0.112)$ & $(0.122)$ \\
\hline \multirow[t]{2}{*}{$\Delta$ Payroll } & & & 0.039 & 0.079 & & 0.173 & 0.156 & 0.212 \\
\hline & & & $(0.108)$ & $(0.137)$ & & $(0.134)$ & $(0.105)$ & $(0.136)$ \\
\hline \multirow[t]{2}{*}{ Related } & $0.296^{* *}$ & $0.318^{* *}$ & $0.303^{* *}$ & $0.327^{* *}$ & $0.287^{* *}$ & $0.305^{* *}$ & $0.274^{* *}$ & $0.303^{* *}$ \\
\hline & $(0.133)$ & $(0.144)$ & $(0.136)$ & $(0.149)$ & $(0.142)$ & $(0.147)$ & $(0.135)$ & $(0.147)$ \\
\hline \multirow[t]{2}{*}{ Private } & $-0.197^{* *}$ & $-0.256^{* * *}$ & $-0.184^{* *}$ & $-0.242^{* *}$ & $-0.275^{* * *}$ & $-0.257^{* * *}$ & $-0.231^{* *}$ & $-0.274^{* * *}$ \\
\hline & $(0.090)$ & $(0.098)$ & $(0.091)$ & $(0.098)$ & $(0.098)$ & $(0.099)$ & $(0.082)$ & $(0.099)$ \\
\hline \multirow[t]{2}{*}{ All cash } & $-0.567^{* * *}$ & $-0.584^{* * *}$ & $-0.558^{* * *}$ & $-0.567^{* * *}$ & $-0.570^{* * *}$ & $-0.545^{* * *}$ & $-0.547^{* * *}$ & $-0.562^{* * *}$ \\
\hline & $(0.099)$ & $(0.118)$ & $(0.099)$ & $(0.118)$ & $(0.111)$ & $(0.110)$ & $(0.091)$ & $(0.112)$ \\
\hline \multirow[t]{2}{*}{ Some stock } & -0.226 & -0.227 & -0.217 & -0.209 & $-0.336^{* *}$ & $-0.314^{* *}$ & $-0.338^{* *}$ & $-0.338^{* *}$ \\
\hline & $(0.165)$ & $(0.189)$ & $(0.164)$ & $(0.190)$ & $(0.184)$ & $(0.183)$ & $(0.161)$ & $(0.184)$ \\
\hline \multirow[t]{2}{*}{ 52-W High Price } & & & & & $0.520^{* *}$ & $0.528^{* * *}$ & $0.558^{* * *}$ & $0.536^{* * *}$ \\
\hline & & & & & $(0.157)$ & $(0.158)$ & $(0.152)$ & $(0.159)$ \\
\hline \multirow[t]{2}{*}{ Log(Asset) } & & $0.057^{*}$ & & $0.058^{*}$ & $0.071^{* *}$ & $0.074^{* *}$ & & $0.076^{* *}$ \\
\hline & & $(0.034)$ & & $(0.035)$ & $(0.035)$ & $(0.037)$ & & $(0.037)$ \\
\hline \multirow[t]{2}{*}{ Market-to-book } & & $-0.107^{* * *}$ & & $-0.112^{* * *}$ & $-0.138^{* * *}$ & $-0.147^{* * *}$ & & $-0.146^{* * *}$ \\
\hline & & $(0.041)$ & & $(0.040)$ & $(0.046)$ & $(0.045)$ & & $(0.045)$ \\
\hline \multirow[t]{2}{*}{ Constant } & $1.061^{* * *}$ & $0.901^{* * *}$ & $1.049^{* * *}$ & $0.884^{* * *}$ & $0.670^{* * *}$ & $0.670^{* * *}$ & $0.862^{* * *}$ & $0.651^{* * *}$ \\
\hline & $(0.098)$ & $(0.236)$ & $(0.098)$ & $(0.236)$ & $(0.240)$ & $(0.240)$ & $(0.085)$ & $(0.248)$ \\
\hline Observations & 1226 & 1004 & 1226 & 1004 & 1004 & 1004 & 1226 & 1004 \\
\hline $\mathrm{R}^{2}$ & 0.04 & 0.04 & 0.03 & 0.04 & 0.09 & 0.09 & 0.10 & 0.09 \\
\hline
\end{tabular}


Table 11: Determinants of Acquirer's CAR

The table reports estimates of a firm-level OLS regression explaining the acquirer's CAR. The sample consists of mergers from the SDC M\&As database in which the announcement date is between 1981 and 2002, the completion date is within 360 days of the announcement, and the target is a publiclylisted firm that can be matched to the ASM/CMF, maintained at U.S. Census Bureau. $\mathrm{CAR}_{(-1,+1)}$ is the three-day cumulative abnormal return for the acquirer using a market model adjusted for CRSP value-weighted market index. TFP is constructed as an employment-weighted sum of all the plants' $\mathrm{TFP}$ for the target firm. $\Delta \mathrm{TFP}=\mathrm{TFP}_{\mathrm{T}+1}-\mathrm{TFP}_{\mathrm{T}-1} ; \Delta$ Payroll $=\mathrm{Log}\left(\right.$ Payroll $\left._{\mathrm{T}+1}\right)-\log \left(\mathrm{Payroll}_{\mathrm{T}-1}\right)$. All Cash is a dummy variable that equals one if the entire transaction value was paid by cash and zero otherwise. Some Stock is a dummy variable that equals one if at least some portion of the transaction was paid by stock and zero otherwise. Private Acquirer is a dummy variable that equals one if the acquirer is not a publicly-listed firm and zero otherwise. Premium is the ratio of transaction value to target's market value 30 trading days before announcement. Related is a dummy variable that equals one if target and acquirer share the same primary 2-digit SIC industry. Log(Assets) is the logarithm of acquirer's book assets. Market-to-book is the ratio of market value to the book value of assets for the acquirer. Heteroskedastic-robust standard errors are in parentheses. All specifications control for target/acquirer industry (2-digit SIC) and year fixed effects. The symbols $* * *, * *$, and * indicate statistical significance at the 1, 5, and 10 percent levels, respectively.

\begin{tabular}{|c|c|c|c|c|c|c|c|c|}
\hline & (1) & $(2)$ & $\begin{array}{c}\text { Dependen } \\
\text { (3) }\end{array}$ & $\begin{array}{c}\text { t Variable: } \\
\text { (4) }\end{array}$ & $\begin{array}{c}\text { Acquirer } \\
(5)\end{array}$ & $\mathrm{AR}_{(-1,+1)}$ & $(7)$ & (8) \\
\hline$\Delta \mathrm{TFP}$ & 0.010 & 0.020 & & & 0.010 & 0.019 & 0.011 & 0.001 \\
\hline & $(0.012)$ & $(0.012)$ & & & $(0.012)$ & $(0.012)$ & $(0.016)$ & $(0.016)$ \\
\hline$\Delta$ Payroll & & & $\begin{array}{c}0.001 \\
(0.007)\end{array}$ & $\begin{array}{r}-0.004 \\
(0.007)\end{array}$ & $\begin{array}{c}0.001 \\
(0.007)\end{array}$ & $\begin{array}{r}-0.002 \\
(0.007)\end{array}$ & $\begin{array}{c}-0.008 \\
(0.009)\end{array}$ & $\begin{array}{c}-0.005 \\
(0.009)\end{array}$ \\
\hline RelaSize & & & & & & & $\begin{array}{c}0.011 \\
(0.012)\end{array}$ & $\begin{array}{c}-0.034^{* *} \\
(0.015)\end{array}$ \\
\hline RelaSize* $\Delta \mathrm{TFP}$ & & & & & & & $\begin{array}{c}-0.008 \\
(0.047)\end{array}$ & $\begin{array}{c}0.116^{* *} \\
(0.057)\end{array}$ \\
\hline RelaSize* $\Delta$ Payroll & & & & & & & $\begin{array}{c}0.047 \\
(0.032)\end{array}$ & $\begin{array}{c}0.023 \\
(0.036)\end{array}$ \\
\hline Related & $\begin{array}{c}0.001 \\
(0.006)\end{array}$ & $\begin{array}{c}0.004 \\
(0.007)\end{array}$ & $\begin{array}{c}0.001 \\
(0.006)\end{array}$ & $\begin{array}{c}0.005 \\
(0.007)\end{array}$ & $\begin{array}{c}0.001 \\
(0.006)\end{array}$ & $\begin{array}{c}0.004 \\
(0.007)\end{array}$ & $\begin{array}{c}0.001 \\
(0.006)\end{array}$ & $\begin{array}{c}0.006 \\
(0.007)\end{array}$ \\
\hline Premium & $\begin{array}{c}-0.001 \\
(0.001)\end{array}$ & $\begin{array}{c}0.004 \\
(0.003)\end{array}$ & $\begin{array}{c}-0.001 \\
(0.001)\end{array}$ & $\begin{array}{c}0.004 \\
(0.003)\end{array}$ & $\begin{array}{c}-0.001 \\
(0.001)\end{array}$ & $\begin{array}{c}0.004 \\
(0.003)\end{array}$ & $\begin{array}{c}-0.001 \\
(0.001)\end{array}$ & $\begin{array}{c}0.003 \\
(0.003)\end{array}$ \\
\hline All cash & $\begin{array}{c}0.002 \\
(0.008)\end{array}$ & $\begin{array}{c}0.006 \\
(0.008)\end{array}$ & $\begin{array}{c}0.003 \\
(0.008)\end{array}$ & $\begin{array}{c}0.007 \\
(0.008)\end{array}$ & $\begin{array}{c}0.002 \\
(0.008)\end{array}$ & $\begin{array}{c}0.006 \\
(0.008)\end{array}$ & $\begin{array}{c}0.002 \\
(0.008)\end{array}$ & $\begin{array}{c}0.003 \\
(0.008)\end{array}$ \\
\hline Some stock & $\begin{array}{c}-0.021^{* *} \\
(0.008)\end{array}$ & $\begin{array}{r}-0.015^{*} \\
(0.009)\end{array}$ & $\begin{array}{c}-0.020^{* *} \\
(0.008)\end{array}$ & $\begin{array}{r}-0.015^{*} \\
(0.009)\end{array}$ & $\begin{array}{c}-0.021^{* *} \\
(0.008)\end{array}$ & $\begin{array}{r}-0.015^{*} \\
(0.009)\end{array}$ & $\begin{array}{c}-0.021^{* *} \\
(0.008)\end{array}$ & $\begin{array}{c}-0.017^{* *} \\
(0.009)\end{array}$ \\
\hline Log(Asset) & & $\begin{array}{c}-0.005^{* *} \\
(0.002)\end{array}$ & & $\begin{array}{c}-0.005^{* *} \\
(0.002)\end{array}$ & & $\begin{array}{c}-0.005^{* *} \\
(0.002)\end{array}$ & & $\begin{array}{c}-0.006^{* * *} \\
(0.002)\end{array}$ \\
\hline Market-to-book & & $\begin{array}{c}-0.004^{* *} \\
(0.002)\end{array}$ & & $\begin{array}{r}-0.004^{*} \\
(0.002)\end{array}$ & & $\begin{array}{r}-0.004^{*} \\
(0.002)\end{array}$ & & $\begin{array}{c}-0.005^{* *} \\
(0.002)\end{array}$ \\
\hline Constant & $\begin{array}{c}0.006 \\
(0.010)\end{array}$ & $\begin{array}{c}0.033^{* *} \\
(0.015)\end{array}$ & $\begin{array}{c}0.005 \\
(0.010)\end{array}$ & $\begin{array}{c}0.032^{* *} \\
(0.015)\end{array}$ & $\begin{array}{c}0.006 \\
(0.010)\end{array}$ & $\begin{array}{c}0.033^{* *} \\
(0.015)\end{array}$ & $\begin{array}{c}0.003 \\
(0.010)\end{array}$ & $\begin{array}{l}0.053^{* * *} \\
(0.018)\end{array}$ \\
\hline Observations & 660 & 459 & 660 & 459 & 660 & 459 & 660 & 459 \\
\hline $\mathrm{R}^{2}$ & 0.02 & 0.06 & $0.02_{47}$ & 0.06 & 0.02 & 0.06 & 0.03 & 0.08 \\
\hline
\end{tabular}




\section{Table 12: Wealth Redistribution between Employees and Shareholders in Dollars}

The table reports estimates of a firm-level OLS regression explaining announcement returns in dollar amount. The sample consists of mergers from the SDC M\&As database in which the announcement date is between 1981 and 2002, the completion date is within 360 days of the announcement, and the target is a publicly-listed firm that can be matched to the ASM/CMF, maintained at U.S. Census Bureau. Dollar Combined $\mathrm{CAR}_{(-1,+1)}$ is the sum of target's Dollar $\mathrm{CAR}_{(-1,+1)}$ (calculated as the product of target's $\mathrm{CAR}_{(-1,+1)}$ and target's market value) and acquirer's Dollar $\mathrm{CAR}_{(-1,+1)}$ (calculated as the product of acquirer's $\mathrm{CAR}_{(-1,+1)}$ and acquirer's market value). $\Delta$ Dollar Payroll $=$ Dollar Payroll ${ }_{\mathrm{T}+1}-$ Dollar Payroll $_{\mathrm{T}-1}$ where the total payroll is expressed in 2005 dollars. All Cash is a dummy variable that equals one if the entire transaction was paid by cash and zero otherwise. Some Stock is a dummy variable that equals one if at least some portion of the transaction was paid by stock and zero otherwise. Private Acquirer is a dummy variable that equals one if the acquirer is not a publicly-listed firm and zero otherwise. Premium is the ratio of transaction value to target's market value 30 trading days before announcement. Related is a dummy variable that equals one if target and acquirer share the same primary 2-digit SIC industry. Log(Assets) is the logarithm of the target's book assets. Market-to-book is the ratio of market value to the book value of assets for the target. $\log$ (AssetsAcquirer) is the logarithm of acquirer's book assets. Market-to-bookAcquirer is the ratio of market value to the book value of assets for the acquirer. All specifications control for target/acquirer industry (2-digit SIC) and year fixed effects. Heteroskedastic-robust standard errors are in parentheses. The symbols ${ }^{* * *},{ }^{* *}$, and ${ }^{*}$ indicate statistical significance at the 1,5 , and 10 percent levels, respectively.

\begin{tabular}{|c|c|c|c|c|c|c|}
\hline & \multicolumn{3}{|c|}{ Dollar Premium } & \multicolumn{3}{|c|}{ Dollar Combined CAR } \\
\hline & $(1)$ & $(2)$ & $(3)$ & $(4)$ & $(5)$ & $(6)$ \\
\hline$\Delta$ Dollar Payroll & $\begin{array}{c}-5.46^{* * *} \\
(1.14)\end{array}$ & $\begin{array}{c}-1.972^{*} \\
(1.20)\end{array}$ & $\begin{array}{c}-5.80^{* * *} \\
(1.73)\end{array}$ & $\begin{array}{c}-1.16 \\
(1.00)\end{array}$ & $\begin{array}{c}-1.62 \\
(1.23)\end{array}$ & $\begin{array}{c}-0.75 \\
(1.13)\end{array}$ \\
\hline 52w High Price & $\begin{array}{c}-40.31 \\
(30.88)\end{array}$ & $\begin{array}{c}-12.96 \\
(31.47)\end{array}$ & $\begin{array}{c}-66.91 \\
(55.71)\end{array}$ & & & \\
\hline Related & $\begin{array}{l}215.66^{* * *} \\
(68.06)\end{array}$ & $\begin{array}{l}159.97^{* * *} \\
(57.28)\end{array}$ & $\begin{array}{l}123.41 \\
(81.75)\end{array}$ & $\begin{array}{c}84.51 \\
(74.91)\end{array}$ & $\begin{array}{c}69.06 \\
(72.44)\end{array}$ & $\begin{array}{c}71.58 \\
(76.29)\end{array}$ \\
\hline All Cash & $\begin{array}{c}-115.52^{* *} \\
(47.72)\end{array}$ & $\begin{array}{l}-9.98 \\
(40.77)\end{array}$ & $\begin{array}{c}-242.80^{* *} \\
(78.83)\end{array}$ & $\begin{array}{c}-190.67^{* *} \\
(79.64)\end{array}$ & $\begin{array}{c}-66.56 \\
(77.53)\end{array}$ & $\begin{array}{c}-194.66^{* *} \\
(95.09)\end{array}$ \\
\hline Some Stock & $\begin{array}{l}408.57^{* * *} \\
(85.38)\end{array}$ & $\begin{array}{c}192.03^{*} \\
(69.31)\end{array}$ & $\begin{array}{c}156.13 \\
(106.86)\end{array}$ & $\begin{array}{c}-184.47^{* *} \\
(86.11)\end{array}$ & $\begin{array}{c}-205.68^{* *} \\
(85.55)\end{array}$ & $\begin{array}{r}-170.25^{*} \\
(100.54)\end{array}$ \\
\hline Log(Asset) & & $\begin{array}{l}293.88^{* * *} \\
(29.14)\end{array}$ & & & $\begin{array}{l}155.42^{* * *} \\
(39.89)\end{array}$ & \\
\hline Market-to-book & & $\begin{array}{l}141.29^{* * *} \\
(46.86)\end{array}$ & & & $\begin{array}{c}-18.86 \\
(52.83)\end{array}$ & \\
\hline Log(AssetAcquirer) & & & $\begin{array}{l}178.96^{* * *} \\
(23.72)\end{array}$ & & & $\begin{array}{c}67.28^{* *} \\
(30.19)\end{array}$ \\
\hline Market-to-bookAcquirer & & & $\begin{array}{l}91.94^{* * *} \\
(36.67)\end{array}$ & & & $\begin{array}{c}-107.21^{* * *} \\
(39.23)\end{array}$ \\
\hline Constant & $\begin{array}{l}181.16^{\text {*** }} \\
(36.97)\end{array}$ & $\begin{array}{c}-1577.9^{* * *}- \\
(169.24)\end{array}$ & $\begin{array}{c}-1143.91^{* * *} \\
(178.33)\end{array}$ & $\begin{array}{c}313.94 \\
(71.41)\end{array}$ & $\begin{array}{c}-538.94^{* *} \\
(233.76)\end{array}$ & $\begin{array}{l}-34.61 \\
(218.44)\end{array}$ \\
\hline Observations & 1226 & 1004 & 513 & 660 & 562 & 459 \\
\hline $\mathrm{R}^{2}$ & 0.14 & 0.40 & 0.29 & 0.02 & 0.10 & 0.07 \\
\hline
\end{tabular}


Table 13: Redistribution between Employees and Shareholders from Fringe Benefits

The table reports estimates of a firm-level OLS regression explaining announcement returns. The sample consists of mergers from the SDC M\&As database in which the announcement date is between 1981 and 2002, the completion date is within 360 days of the announcement, and the target is a publiclylisted firm that can be matched to the ASM/CMF, maintained at U.S. Census Bureau. $\mathrm{CAR}_{(-1,+1)}$ is the three-day cumulative abnormal return estimated using a market model adjusted for CRSP valueweighted market index. TFP is constructed as an employment-weighted sum of all of the plants' TFP for the target firm. $\Delta \mathrm{X}=\log \left(\mathrm{X}_{\mathrm{T}+1}\right)-\log \left(\mathrm{X}_{\mathrm{T}-1}\right)$ where $\mathrm{X}$ includes Fringe Benefits, Total Employment, and Wage rate. All Cash is a dummy variable that equals one if the entire transaction was paid by cash and zero otherwise. Some Stock is a dummy variable that equals one if at least some portion of the transaction was paid by stock and zero otherwise. Private Acquirer is a dummy variable that equals one if the acquirer is not a publicly-listed firm and zero otherwise. Premium is the ratio of transaction value to target's market value of 30 trading days before announcement. Related is a dummy variable that equals one if target and acquirer share the same primary 2-digit SIC industry. 52-W High Price is the ratio of target's highest price in the previous 52 weeks to target's price 30 days before announcement. Log(Assets) is the logarithm of the acquirer's book assets. Market-to-book is the ratio of market value to the book value of assets for the acquirer. All specifications control for target/acquirer industry (2-digit SIC) and year fixed effects. Heteroskedastic-robust standard errors are in parentheses. The symbols ${ }^{* * *},{ }^{* *}$, and ${ }^{*}$ indicate statistical significance at the 1,5 , and 10 percent levels, respectively.

\begin{tabular}{|c|c|c|c|c|c|c|}
\hline & \multicolumn{2}{|c|}{ Premium } & \multicolumn{2}{|c|}{ Acquirer CAR } & \multicolumn{2}{|c|}{ Combined CAR } \\
\hline & (1) & (2) & $(3)$ & (4) & $(5)$ & $(6)$ \\
\hline$\Delta$ Fringe Benefits & $\begin{array}{c}0.126 \\
(0.102)\end{array}$ & & $\begin{array}{c}0.003 \\
(0.006)\end{array}$ & & $\begin{array}{c}-0.003 \\
(0.008)\end{array}$ & \\
\hline$\Delta$ Employment & & $\begin{array}{c}0.241^{*} \\
(0.126)\end{array}$ & & $\begin{array}{c}-0.002 \\
(0.007)\end{array}$ & & $\begin{array}{r}-0.002 \\
(0.010)\end{array}$ \\
\hline$\Delta$ Wage Rate & & $\begin{array}{c}0.064 \\
(0.245)\end{array}$ & & $\begin{array}{c}-0.008 \\
(0.015)\end{array}$ & & $\begin{array}{c}0.015 \\
(0.021)\end{array}$ \\
\hline Related & $\begin{array}{c}0.295^{* *} \\
(0.121)\end{array}$ & $\begin{array}{c}0.306^{* *} \\
(0.121)\end{array}$ & $\begin{array}{c}0.006 \\
(0.007)\end{array}$ & $\begin{array}{c}0.006 \\
(0.007)\end{array}$ & $\begin{array}{l}0.027^{* * *} \\
(0.009)\end{array}$ & $\begin{array}{l}0.027^{* * *} \\
(0.009)\end{array}$ \\
\hline All cash & $\begin{array}{c}-0.570^{* * *} \\
(0.130)\end{array}$ & $\begin{array}{c}-0.557^{* * *} \\
(0.130)\end{array}$ & $\begin{array}{c}0.004 \\
(0.008)\end{array}$ & $\begin{array}{c}0.004 \\
(0.008)\end{array}$ & $\begin{array}{c}-0.002 \\
(0.011)\end{array}$ & $\begin{array}{c}-0.002 \\
(0.011)\end{array}$ \\
\hline Some stock & $\begin{array}{c}-0.337^{* *} \\
(0.153)\end{array}$ & $\begin{array}{c}-0.336^{* *} \\
(0.153)\end{array}$ & $\begin{array}{r}-0.016^{*} \\
(0.008)\end{array}$ & $\begin{array}{r}-0.016^{*} \\
(0.009)\end{array}$ & $\begin{array}{c}-0.03^{* * *} \\
(0.011)\end{array}$ & $\begin{array}{c}-0.03^{* * *} \\
(0.011)\end{array}$ \\
\hline Log(Asset) & $\begin{array}{c}0.074^{* *} \\
(0.033)\end{array}$ & $\begin{array}{c}0.078^{* *} \\
(0.032)\end{array}$ & $\begin{array}{c}-0.005^{* *} \\
(0.002)\end{array}$ & $\begin{array}{c}-0.005^{* *} \\
(0.002)\end{array}$ & $\begin{array}{c}-0.007^{* * *} \\
(0.002)\end{array}$ & $\begin{array}{c}-0.007^{* * *} \\
(0.002)\end{array}$ \\
\hline Market-to-book & $\begin{array}{c}-0.145^{* *} \\
(0.054)\end{array}$ & $\begin{array}{c}-0.153^{* * *} \\
(0.054)\end{array}$ & $\begin{array}{r}-0.004^{*} \\
(0.002)\end{array}$ & $\begin{array}{r}-0.004^{*} \\
(0.002)\end{array}$ & $\begin{array}{c}-0.008^{* * *} \\
(0.003)\end{array}$ & $\begin{array}{c}-0.008^{* * *} \\
(0.003)\end{array}$ \\
\hline 52-W High Price & $\begin{array}{l}0.531^{* * *} \\
(0.075)\end{array}$ & $\begin{array}{l}0.538^{* * *} \\
(0.075)\end{array}$ & $\begin{array}{r}-0.009^{*} \\
(0.005)\end{array}$ & $\begin{array}{r}-0.009^{*} \\
(0.005)\end{array}$ & $\begin{array}{c}-0.009 \\
(0.007)\end{array}$ & $\begin{array}{c}-0.009 \\
(0.007)\end{array}$ \\
\hline Constant & $\begin{array}{l}0.645^{\text {*** }} \\
(0.232)\end{array}$ & $\begin{array}{l}0.658^{* * *} \\
(0.231)\end{array}$ & $\begin{array}{l}0.042^{\text {*** }} \\
(0.015)\end{array}$ & $\begin{array}{l}0.043^{* * *} \\
(0.015)\end{array}$ & $\begin{array}{l}0.119^{* * *} \\
(0.021)\end{array}$ & $\begin{array}{l}0.118^{* * *} \\
(0.021)\end{array}$ \\
\hline Observations & 1004 & 1004 & 459 & 459 & 459 & 459 \\
\hline $\mathrm{R}^{2}$ & 0.09 & 0.09 & 0.06 & 0.06 & 0.10 & 0.10 \\
\hline
\end{tabular}

